\section{A Risk Assessment Model for Importation of United States Milling Wheat Containing Tilletia contraversa}

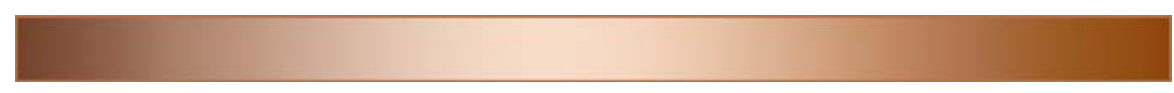

G. L. Peterson
USDA-ARS-FDWSRU, Fort Detrick,
MD 21702, USA
T. B. Whitaker
USDA-ARS-MQHRU, NC State
University, Raleigh, NC 27695, USA
R. J. Stefanski
WMO-WCP-AGM Case postale No.
2300, CH-1211 Geneva 2, Switzerland
E. V. Podleckis
USDA-APHIS-PPD, Riverdale, MD
20737, USA
J. G. Phillips
19038, USA
J. S. Wu
USDA-ARS-NAA, Wyndmoor, PA
U.S. Census Bureau, 4700 Silver Hill
Road, Washington, DC 20233
W. H. Martinez
USDA-ARS-NAA, USA

Dwarf bunt of wheat, caused by the fungal pathogen Tilletia contraversa J.G. Kühn, infects fall sown (winter) wheat. Symptoms of this systemic disease include increased tillering, dwarfing, and shorted culms (Fig. 1A). Typically in infected plants, developing seeds are replaced by fungal sori containing teliospores (Fig. 1B). Harvesting and processing of infected grain, including conveyance, mixing, and blending operations, rupture the sori and release teliospores (Fig. 1C) into the grain. At the farm level, when $T$. contraversasusceptible cultivars are grown in a dwarf bunt-conducive area, disease can result in loss of grain quality. Such grain is rejected as "smutty" under United States Department of Agriculture (USDA) grain quality standards (37) and is diverted to animal feed and not introduced into the U.S. export conveyance system. As a result of these standards, the levels of $T$. contraversa teliospores in export grain are generally low $(19,25,42)$.

Teliospores of $T$. contraversa commonly occur at detectable levels in U.S. wheat export shipments originating from the Pacific Northwest (PNW) (35; G. L. Peterson, personal observation). In the United States, dwarf bunt historically has been observed in approximately $1.4 \%$ of the total winter wheat acreage (14) and primarily in specific areas of the PNW and western intermountain areas (Fig. 2). To-

Corresponding author: G. L. Peterson, USDAARS-FDWSRU, 1301 Ditto Ave., Fort Detrick, MD 21702; E-mail: gary.peterson@ars.usda.gov

doi:10.1094/PDIS-93-6-0560

This article is in the public domain and not copyrightable. It may be freely reprinted with customary crediting of the source. The American Phytopathological Society, 2009. day, in regions where the disease once occurred commonly, the use of resistant cultivars (11) and difenoconazole seed treatments $(18,32)$ effectively reduced the levels of disease to trace amounts in commercial fields. Because of the strict environmental requirements for disease establishment, management methods need only be used in areas where the disease has been reported. USDA does not regulate the movement of $T$. contravers $a$-infested grain from these regions for fear of further spread. Sometimes, farmers planting in areas that frequently do not have conducive conditions will risk planting higher yielding susceptible cultivars, which occasionally results in significant levels of infection and higher levels of teliospores in the grain conveyance system.

The biology and epidemiology of this pathogen have been well documented in more than 75 years of published research and field observations $(2,10,11,14,21,33)$. Infection occurs after host plants enter winter dormancy and only through tillering initials present during a relatively narrow window of time during plant development. Germination of teliospores requires both stable high-moisture conditions and temperatures between -2 and $10^{\circ} \mathrm{C}$ for 3 to 8 weeks. Temperatures above $10^{\circ} \mathrm{C}$ inhibit germination. Only teliospores at or near the soil surface germinate to release basidiospores that initiate the infection process. Worldwide, localized yield losses are most often observed in regions with 60 or more days of continuous snow cover over unfrozen soil, which provides sufficiently high levels of soil moisture, relative humidity, and stable temperatures for teliospore germination while also protecting basidiospores and sporidia from desiccation. $(2,13,14,24,36)$. Temperatures at the soil-snow interface range from -2 to $+3^{\circ} \mathrm{C}$, well within the optimal range for teliospore germination and host infection $(13,14,17,35)$.

Fifteen countries (Algeria, Brazil, Canada, Chile, People's Republic of China [PRC], Czech Rep/Slovakia, India, Macedonia, Morocco, New Zealand, Paraguay, Poland, South Africa, Tunisia, and Turkey) have documented regulatory restrictions against the importation of $T$. contraversainfested wheat. The disease has been reported in five of the 15 countries.

The USDA Agricultural Research Service (ARS), in response to U.S. wheat industry concerns over the 34-year embargo by the PRC of U.S. wheat exports from the PNW, convened a multinational, multidisciplinary working group to conduct a pest risk assessment to evaluate and give insight into the potential risk of the introduction of dwarf bunt to new areas by the import of U.S. wheat for commercial milling and the likelihood of an adverse impact on their wheat production. The working group consisted of scientists and other participants from government agencies, universities, and industry from the United States, Sweden, Canada, Germany, and Mexico (see acknowledgments).

Based on the extensive quantity of published research on the biology, epidemiology, and disease control of dwarf bunt, we proposed that a quantitative, as opposed to qualitative, approach to this risk assessment would be possible. A quantitative mathematical model approach would greatly increase the utility of this assessment, in that individual components (data distributions) of the model could be easily customized for different countries and used to test the effects of changes in the import pathways or the effects of risk mitigation actions.

According to Sansford (30), "Quantitative analyses are more feasible and com- 


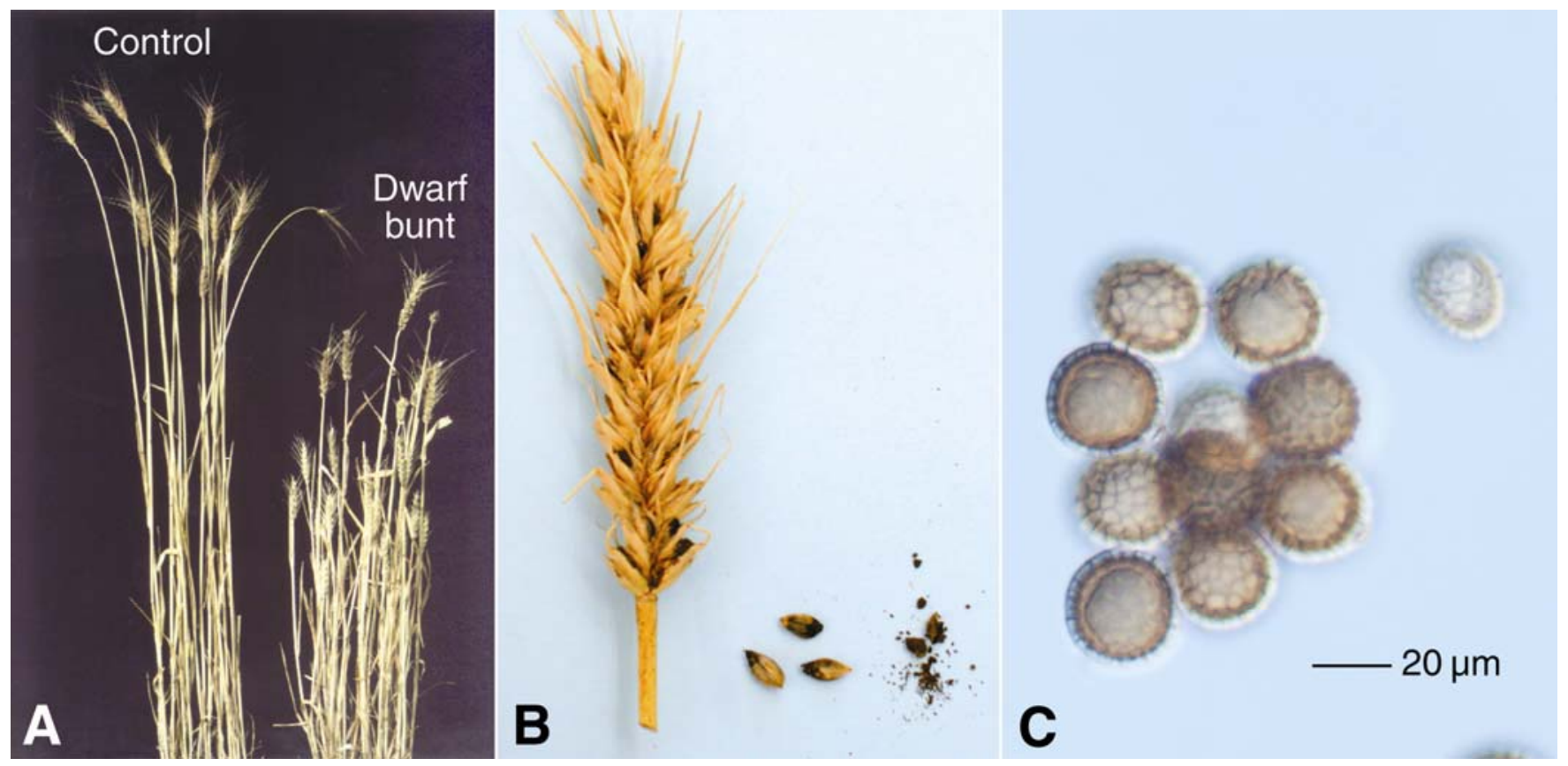

Fig. 1. A, Dwarfing symptoms of a Tilletia contraversa-infected wheat plant (right) compared to a healthy plant (left). B, Infected wheat spike with $T$. contraversa intact and ruptured sori. C, T. contraversa teliospores.

mon in engineering and related disciplines. However, in biological disciplines, a lack of basic data often is a limiting factor in using fully quantitative methods." Similarly, Vose (38) stated, "A quantitative PRA that uses poor data, an incorrect model or an inappropriate technique has less scientific validity than a semi-quantitative/ qualitative PRA based on good research data and other literature". With these requirements in mind, despite the volume of existing published research, the development of a quantitative model required generating data for several elements unique to this project. ARS, in cooperation with other USDA agencies, the U.S. wheat industry, and university scientists, conducted studies which included the quantitative determination of the fate of teliospores during milling (3); development of sampling methods to estimate the levels of teliospores in U.S. wheat export shipments (42); a quantitative survey of $T$. contraversa teliospores in U.S. exports; and determination of the relationship between the number of teliospores in the soil and levels of disease produced under diseaseconducive conditions (12).

The objective of this article is to describe and present examples of how the $T$. contraversa-risk model (TCK-risk model) was developed and successfully used in the presentation of risk assessments to convince Brazil, Peru, and Mexico not to regulate, and the PRC to end the 34-year embargo and establish a tolerance level for TCK teliospores in import shipments.

\section{TCK-Risk Model}

Scenario analysis was utilized to describe the events that would have to occur before dwarf bunt could become estab-

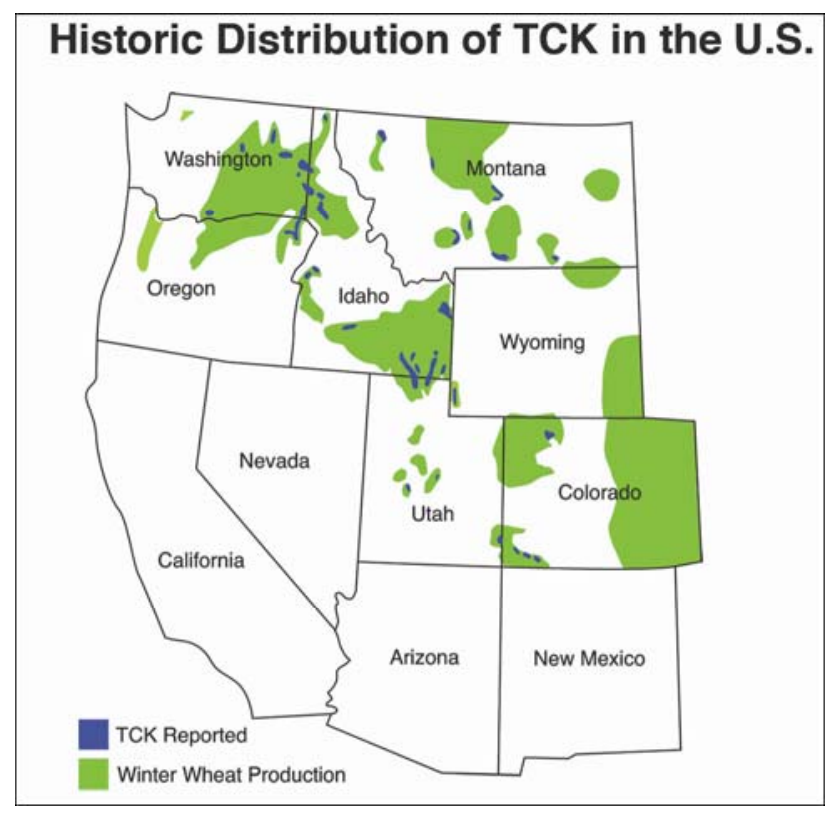

Fig. 2. Map of reported historical distribution of dwarf bunt (TCK) of wheat in the United States (35) showing areas where the disease occurred in relation to winter wheat growing areas prior to the success of current control measures.

lished in a winter wheat growing region. The model developed in this risk assessment is diagrammed in Figure 3. The model estimates the number of spores introduced onto disease-conducive wheat hectares relative to the threshold level of spores unlikely to initiate disease introduction (12). If the number of spores per conducive hectare exceeds the estimated per hectare disease threshold, then dwarf bunt introduction is possible.

To estimate the average number of spores per conducive-hectare of wheat (C14), the model estimates the number of spores that reach the wheat hectares $(\mathrm{C} 13)$ and divides them by the number hectares with a dwarf bunt favorable environment (F4).

The number of spores to reach the disease-conducive wheat hectares is determined as shown by $\mathrm{C} 11$. In essence, this node shows how many spores arrive in imported wheat annually (C3) and the percentage of these spores that are dispersed to disease-conducive hectares (C10). The methods by which spores from grain for milling can be dispersed are detailed in $\mathrm{C} 7$. Some of the spores reach 
winter wheat fields via handling and milling (C4), and some spores are spread into fields after milling via millfeed and manure (C6).

The final estimate of the risk of introducing dwarf bunt is a function of the nodes, the mathematical relationship between the nodes, and the values estimated for the probabilities at each node. Major nodes in the scenario analysis represent independent events that can occur before dwarf bunt can become established in a wheat field. The mathematical relationship between the major nodes is expressed as a linear, multiplicative model. In some instances, major nodes may encompass multiple events, each contributing to the total probability estimate for that node. In this case, the mathematical relationship between the subnodes is expressed as the sum of the probabilities for each subnode. For example, the probability that viable teliospores will escape during the milling process is a major node. But there are a number of pathways during the milling process that could lead to their dispersal (subnodes), such as the proportion of spores escaping through house air filters or millfeed spillage during handling and mixing.

Upon arrival of $T$. contraversa-contaminated grain at the importing country, teliospores could be spread to wheat fields by several pathways. These include air disper- sal during offloading and transport to commercial mills, direct diversion of the grain for use as planting seed, air dispersal during milling, contamination from millfeed lost during transport, and accumulation of spores in manure from animals fed the $T$. contraversa-contaminated millfeed. The model assumes that all escaping teliospores arrive in a winter wheat field.

\section{Geophytopathological Model}

Although the concept of geophytopathology was presented decades ago $(26,40,41)$, relatively little research has been conducted in the field. Its potential merits, however, were recognized by Coakley et al (8) and Zadoks (43). The principle of adapting a weather-based disease forecast model to one for assessment of long-term regional disease risk was effectively demonstrated by Coakley et al. (4-7), who modified a model for stripe rust on winter wheat to accept daily weather data instead of monthly averages.

The dwarf bunt geophytopathological model (TCK-GM) integrates a wheat growth model with climate parameters in order to estimate the number of hectares within a country that may be conducive to disease introduction and significant reduction of yield. The very specific requirements of climate, growth cycle in the host, and germination cycle of the organism for wheat infection by $T$. contraversa readily lend themselves to the development of a model. As a critical subroutine within the TCK-risk model, the TCK-GM provides the location, annual frequency, and proportion of potential wheat hectares conducive to dwarf bunt introduction and establishment. The weather data come from a network of daily weather stations throughout much of the world that collect and transmit to global data centers through the United Nations World Meteorological Organization's (WMO) telecommunications network. The data include daily maximum and minimum air temperatures, precipitation, and weather codes that depict rain, snow, or clear weather every 3 hours. For our assessments, stations selected were those that had at least $75 \%$ of the data available over a 15-year time period (1982 to 1997). All weather data used for Brazil, China, Mexico, and Peru were supplied by the USDA's Joint Agricultural Weather Facility (JAWF) from the WMO network. The parameters of snow cover, surface soil temperatures, and the period of winter wheat tillering were generated by the procedures described in the following paragraphs.

A model developed by the JAWF to estimate snow cover and depth, based on accepted meteorological principles of snow accumulation and melting $(1,20)$, has been used in Europe and Asia for over 20 years. The model first determines if any snow has

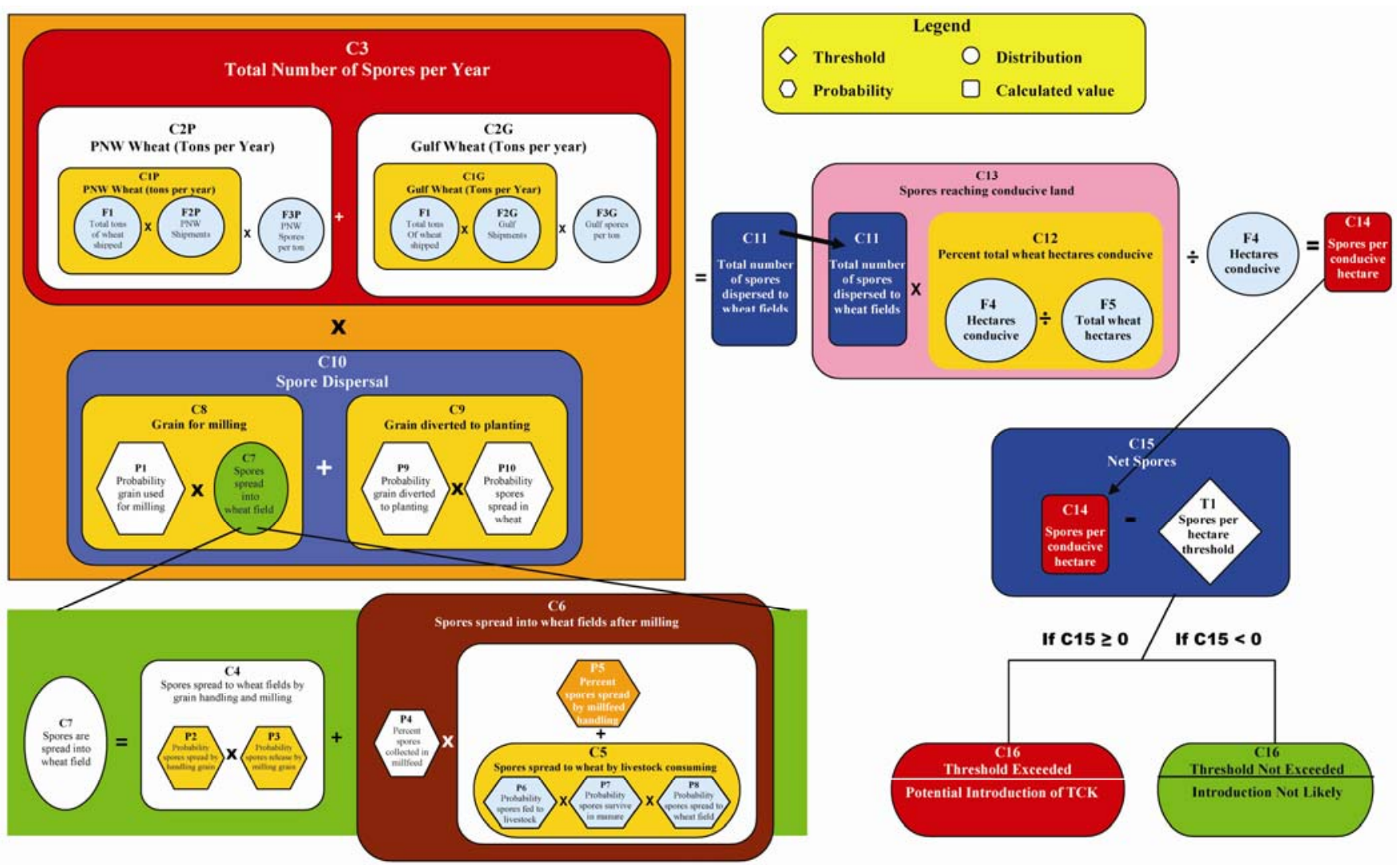

Fig. 3. Flow diagram illustrating various nodes and input variables associated with the general linear Tilletia contraversa-risk model beginning with loading of teliospore-contaminated milling wheat and ending with final deposition of teliospores on hectares of land favorable for disease development. 
fallen by examining the 3-hourly weather codes. If these codes are incomplete or missing for a given day, snow is estimated. If the mean temperature is less than $1{ }^{\circ} \mathrm{C}$, then snow is assumed to have occurred or remained at the standard ratio of $1 \mathrm{~cm}$ rain to $10 \mathrm{~cm}$ snow. If the weather codes are present, this ratio is modified by the presence of snow, rain, or sleet codes. Snow melt is assumed when either the maximum temperature is greater than $1^{\circ} \mathrm{C}$ or rain has occurred. Snow cover is determined by subtracting the snow melt from the snow. If snow cover is calculated as less than zero, then the model value is set at zero.

Maximum and minimum surface soil temperatures are estimated from relationships in the Crop Environment Resource Synthesis (CERES)-WHEAT crop model (28). Surface soil temperature is a function of the air temperature and solar radiation at the surface. Solar radiation at the top of the atmosphere is estimated from day of year and latitude relationships; however, estimating the transmission of solar radiation through the atmosphere is very complex and difficult. For this reason, estimates of transmission for Brazil, China, Mexico, and Peru were based on relationships developed for the United States. The period of winter wheat tillering was estimated in wheat development routines from the wheat growth model MODWHT3 (27). Inputs to these routines are growing degree days, maximum and minimum air temperatures, and planting dates.

Wheat hectares conducive to dwarf bunt. Two variants of the TCK-GM were developed. The first model variant assumes that the introduction of $T$. contraversa leading to potential yield loss requires 60 or more days of continuous snow cover of more than $1 \mathrm{~cm}$ when wheat is at a susceptible growth stage. These conditions were used in the TCK-GM to develop the "Yield Loss scenario", based on observations by researchers in the United States, Canada, and Europe $(9,15-17,29,32)$. The second TCK-GM model variant, proposed by Chinese colleagues $(39,44)$, assumes that dwarf bunt could be introduced when 42 or more days of precipitation occurred while surface soil temperatures stayed between 2 and $10^{\circ} \mathrm{C}$ during tiller development. The days did not have to be contiguous, but all conditions must occur on the same day for that day to be counted as part of the 42 or more days favorable for dwarf bunt. In this TCK-GM, these environmental requirements, combined with those of the Yield Loss scenario, were used to develop the "Introduction scenario". Its purpose was to identify not only regions where dwarf bunt may become established and cause yield loss, but areas where measurable agronomic yield loss would not be expected, but the disease may occur infrequently and at low levels.

A mathematical approach was necessary because the extent of the winter wheat growing areas in each state is not known precisely and the amount planted varies from year to year, especially for Brazil, China, India, and Peru where the resolution is limited to the reported number of hectares of wheat planted in each state or province each year. We assumed that the reported hectares of winter wheat grown in each state or province each year were distributed evenly across each state or province.

Hectare estimates of dwarf bunt-conducive winter wheat were summed for each state or province, and the number of years these conditions occurred over the 15-year period was calculated and grouped within frequency intervals from 5 to $95 \%$. Using the results from the Introduction scenario and the Yield Loss scenario, Frequency maps for dwarf bunt Introduction and potential Yield Loss scenarios were produced using Geographic Information Software (GIS). The GIS was used also to determine the land area favorable for disease (in square kilometers) in each state or province within a country. The proportion of land suitable for disease was calculated and multiplied by the sum of winter wheat

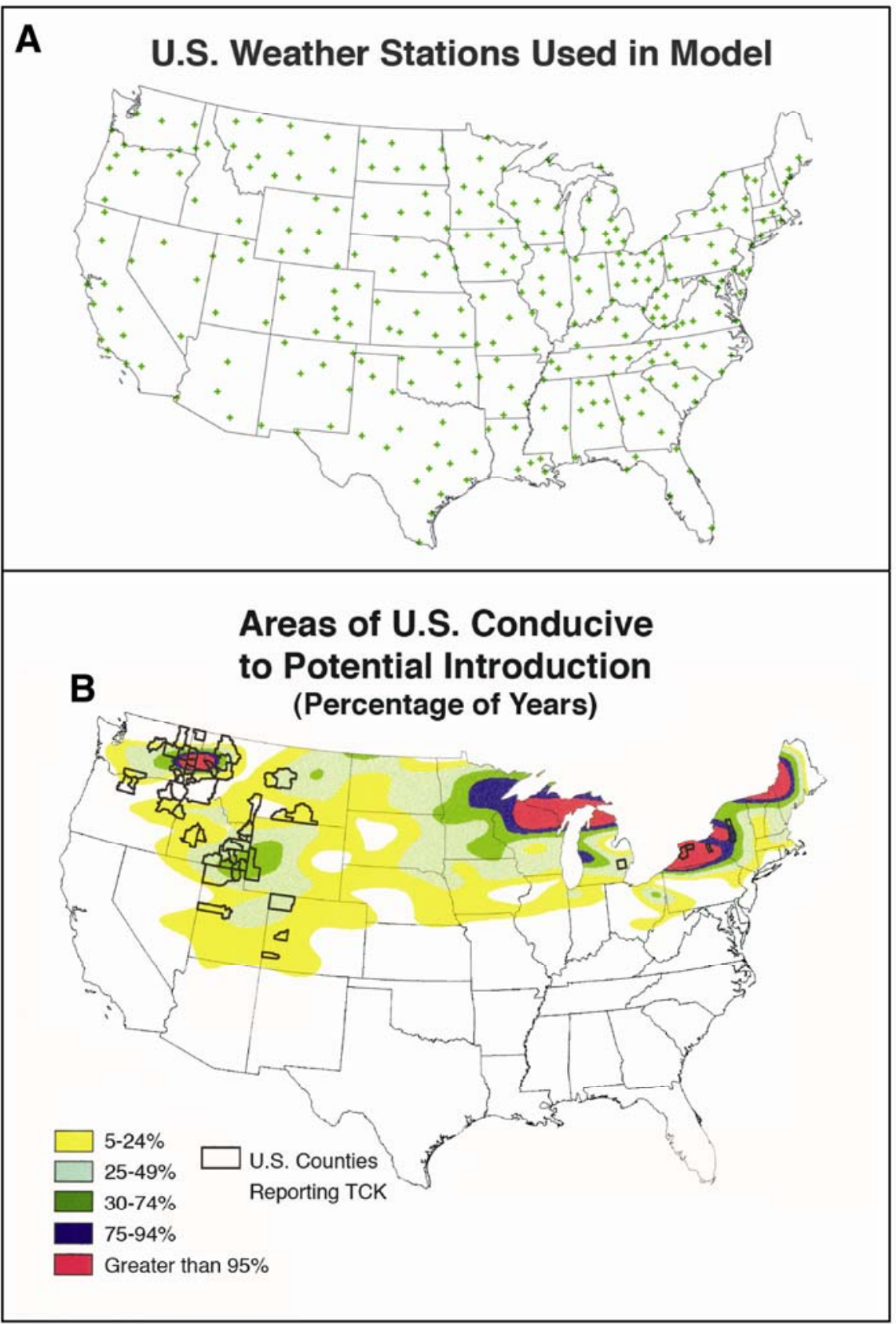

Fig. 4. A, Distribution of U.S. weather stations used in the Geophytopathological Model (TCK-GM) to validate its efficacy in identifying regions favorable to dwarf bunt introduction. B, Regions identified by the TCK-GM as having favorable conditions for dwarf bunt introduction and how often those conditions occur, compared with those counties where the disease has been reported. Areas identified in the Northeast are nonhost spring wheat growing areas. 
hectares in each state to estimate the number of hectares of conducive winter wheat land in each country.

Geophytopathological model validation. In order to validate the sensitivity of the TCK-GM, data were obtained from an equivalent distribution of 150 U.S. weather stations (Fig. 4A) from 1982 to 1997 and used to test the model. GIS mapping results were compared with all U.S. counties where dwarf bunt has been reported. We did not differentiate between counties reporting field infection and historical reports based on herbarium specimens (e.g., two Wyoming counties do not grow wheat; however, the presence of dwarf bunt is recorded in the historic literature). The Introduction scenario was used in the analysis presented here. Results of the analysis showed that $11 \%$ of the U.S. winter wheat hectares had potentially condu- cive conditions for dwarf bunt introduction (Fig. 4B). Using the TCK-GM, the GIS map overlay identified areas where disease-conducive conditions occurred in $50 \%$ or more of the years analyzed. This corresponded well with areas where historically significant incidence of disease once occurred. All counties where dwarf bunt had been reported were identified by the TCK-GM. Because of the snow cover criteria, the model's GIS output also identified the spring wheat growing regions of the central northern United States, although $T$. contraversa does not infect spring wheat. This had no mathematical impact on the TCK-GM model results or those of the TCK-risk model because the output from the TCK-GM is based only on reported hectares of winter wheat.

In addition, the results showed areas where dwarf bunt favorable conditions occurred only 5 to $24 \%$ of the years examined, although the disease has not been reported from most of these areas. Because the favorable conditions did not occur frequently, these regions may likely not support perpetuation of the disease; however, we believe this would convey an added level of comfort to trading partners when considering the final outcome of both the TCK-GM and TCK-risk model analyses.

\section{Generic TCK-Risk Model Nodes and Probability Calculations}

The model, presented in Table 1, was built in a spreadsheet environment with Microsoft Excel 97 with Palisade Corporation's 32 bit @Risk (Ithaca, NY) add-in. Within the presentation of the model, nodes associated with the letter F (F1, F2, etc.) designate cumulative frequency distri-

Table 1. Mathematical sequence of the calculations, variables, and distributions used in the Tilletia contraversa-risk model

\begin{tabular}{|c|c|c|c|c|c|c|}
\hline Var. & Description & Distribution & China & Brazil & Mexico & Peru \\
\hline $\mathrm{F} 1$ & $\begin{array}{l}\text { Annual tons of wheat to importer from all } \\
\text { U.S. origins }\end{array}$ & $\begin{array}{l}\text { Truncated } \\
\text { Normal }\end{array}$ & $\begin{array}{l}19,926,14,516 \\
46-2,410,871\end{array}$ & $\begin{array}{l}25,652 ; 11,321 \\
1,084-57,752\end{array}$ & $\begin{array}{l}668,525 ; 462,557 \\
87,000-1,500,000\end{array}$ & $\begin{array}{l}405,854 ; 216,575 \\
93,000-1,500,000\end{array}$ \\
\hline F2P & Wheat shipped from PNW (\%) & Triangular & $0.3,0.5,0.7$ & $0.3,0.5,0.7$ & $0.3,0.5,0.7$ & $0.3,0.5,0.7$ \\
\hline $\mathrm{F} 2 \mathrm{G}$ & Wheat shipped from Gulf (\%) & Compl. B2 & $1-\mathrm{F} 2 \mathrm{P}$ & 1-F2P & 1-F2P & 1-F2P \\
\hline C1P & Wheat from PNW (tons per year) & & $\mathrm{F} 1 * \mathrm{~F} 2 \mathrm{P}$ & $\mathrm{F} 1 * \mathrm{~F} 2 \mathrm{P}$ & $\mathrm{F} 1 * \mathrm{~F} 2 \mathrm{P}$ & $\mathrm{F} 1 * \mathrm{~F} 2 \mathrm{P}$ \\
\hline $\mathrm{C} 1 \mathrm{G}$ & Wheat from Gulf (tons per year) & & $\mathrm{F} 1 * \mathrm{~F} 2 \mathrm{G}$ & $\mathrm{F} 1 * \mathrm{~F} 2 \mathrm{G}$ & $\mathrm{F} 1 * \mathrm{~F} 2 \mathrm{G}$ & $\mathrm{F} 1 * \mathrm{~F} 2 \mathrm{G}$ \\
\hline F3P & $\begin{array}{l}\text { TCK spores per ton of PNW wheat } \\
(20,000 * \text { count } / 50 \mathrm{~g})\end{array}$ & Empirical & & & & \\
\hline F3G & $\begin{array}{l}\text { TCK spores per ton of Gulf wheat } \\
(20,000 * \text { count } / 50 \mathrm{~g})\end{array}$ & Empirical & & & & \\
\hline $\mathrm{C} 2 \mathrm{P}$ & $\begin{array}{l}\text { Calc. spores from PNW wheat shipments } \\
\text { annually }\end{array}$ & & $\mathrm{C} 1 \mathrm{P} * \mathrm{~F} 3 \mathrm{P}$ & $\mathrm{C} 1 \mathrm{P} * \mathrm{~F} 3 \mathrm{P}$ & $\mathrm{C} 1 \mathrm{P} * \mathrm{~F} 3 \mathrm{P}$ & $\mathrm{C} 1 \mathrm{P} * \mathrm{~F} 3 \mathrm{P}$ \\
\hline $\mathrm{C} 2 \mathrm{G}$ & $\begin{array}{l}\text { Calc. spores from Gulf wheat shipments } \\
\text { annually }\end{array}$ & & $\mathrm{C} 1 \mathrm{G} * \mathrm{~F} 3 \mathrm{G}$ & $\mathrm{C} 1 \mathrm{G} * \mathrm{~F} 3 \mathrm{G}$ & $\mathrm{C} 1 \mathrm{G} * \mathrm{~F} 3 \mathrm{G}$ & $\mathrm{C} 1 \mathrm{G} * \mathrm{~F} 3 \mathrm{G}$ \\
\hline C3 & $\begin{array}{l}\text { Calc. annual spores in U.S. wheat shipments } \\
\text { to importer }\end{array}$ & & $\mathrm{C} 2 \mathrm{P}+\mathrm{C} 2 \mathrm{G}$ & $\mathrm{C} 2 \mathrm{P}+\mathrm{C} 2 \mathrm{G}$ & $\mathrm{C} 2 \mathrm{P}+\mathrm{C} 2 \mathrm{G}$ & $\mathrm{C} 2 \mathrm{P}+\mathrm{C} 2 \mathrm{G}$ \\
\hline P1 & Prob. grain used for commercial milling & Beta & 6,2 & 6,2 & 6,2 & 6,2 \\
\hline P2 & Prob. spores spread by grain handling & Uniform & $0.0025-0.003$ & $0.0025-0.003$ & $0.0025-0.003$ & $0.0025-0.003$ \\
\hline P3 & Prob. spores released by milling grain & Beta & 2,18 & 2,18 & 2,18 & 2,18 \\
\hline $\mathrm{C} 4$ & $\begin{array}{l}\text { Prop. of spores to wheat field by grain } \\
\text { handling and milling }\end{array}$ & & $\mathrm{P} 2+\mathrm{P} 3$ & $\mathrm{P} 2+\mathrm{P} 3$ & $\mathrm{P} 2+\mathrm{P} 3$ & $\mathrm{P} 2+\mathrm{P} 3$ \\
\hline P4 & Prob. spores collected in millfeed & Beta & 4,2 & 4,2 & 4,2 & 4,2 \\
\hline P5 & Prob. spores spread by millfeed handling & Uniform & $0.001-0.01$ & $0.001-0.01$ & $0.001-0.01$ & $0.001-0.01$ \\
\hline P6 & Prob. spores fed to livestock & Beta & 4,2 & 4,2 & 4,2 & 4,2 \\
\hline P7 & Prob. spores survive manure & Uniform & $0.3,0.7$ & $0.3,0.7$ & $0.3,0.7$ & $0.3,0.7$ \\
\hline P8 & $\begin{array}{l}\text { Prob. that spores spread to wheat field via } \\
\text { manure }\end{array}$ & Uniform & $0.4,0.6$ & $0.4,0.6$ & $0.4,0.6$ & $0.4,0.6$ \\
\hline C5 & $\begin{array}{l}\text { Prob. spores spread to field by livestock } \\
\text { consumption }\end{array}$ & & $\mathrm{P} 6 * \mathrm{P} 7 * \mathrm{P} 8$ & $\mathrm{P} 6 * \mathrm{P} 7 * \mathrm{P} 8$ & $\mathrm{P} 6 * \mathrm{P} 7 * \mathrm{P} 8$ & $\mathrm{P} 6 * \mathrm{P} 7 * \mathrm{P} 8$ \\
\hline C6 & Prob. spores to wheat field after milling & & $(\mathrm{P} 5+\mathrm{C} 5) * \mathrm{P} 6$ & $(\mathrm{P} 5+\mathrm{C} 5) * \mathrm{P} 6$ & $(\mathrm{P} 5+\mathrm{C} 5) * \mathrm{P} 6$ & $(\mathrm{P} 5+\mathrm{C} 5) * \mathrm{P} 6$ \\
\hline C7 & Prob. spores spread to wheat field & & $\mathrm{C} 4+\mathrm{C} 6$ & $\mathrm{C} 4+\mathrm{C} 6$ & $\mathrm{C} 4+\mathrm{C} 6$ & $\mathrm{C} 4+\mathrm{C} 6$ \\
\hline $\mathrm{C} 8$ & Prob. spores spread from grain for milling & & $\mathrm{P} 1 * \mathrm{C} 7$ & $\mathrm{P} 1 * \mathrm{C} 7$ & $\mathrm{P} 1 * \mathrm{C} 7$ & $\mathrm{P} 1 * \mathrm{C} 7$ \\
\hline P9 & Prob. grain diverted to planting & Compl. P1 & $1-\mathrm{P} 1$ & $1-\mathrm{P} 1$ & 1-P1 & $1-\mathrm{P} 1$ \\
\hline P10 & Prob. spores spread to wheat field & & 1 & 1 & 1 & 1 \\
\hline C9 & Prob. spores from grain diverted to planting & & $\mathrm{P} 9 * \mathrm{P} 10$ & $\mathrm{P} 9 * \mathrm{P} 10$ & $\mathrm{P} 9 * \mathrm{P} 10$ & $\mathrm{P} 9 * \mathrm{P} 10$ \\
\hline $\mathrm{C} 10$ & $\begin{array}{l}\text { Prob. spores dispersed to wheat field (all } \\
\text { sources) }\end{array}$ & & $\mathrm{C} 8+\mathrm{C} 9$ & $\mathrm{C} 8+\mathrm{C} 9$ & $\mathrm{C} 8+\mathrm{C} 9$ & $\mathrm{C} 8+\mathrm{C} 9$ \\
\hline C11 & Total no. of spores diverted to wheat fields & & $\mathrm{C} 3 * \mathrm{C} 10$ & $\mathrm{C} 3 * \mathrm{C} 10$ & $\mathrm{C} 3 * \mathrm{C} 10$ & $\mathrm{C} 3 * \mathrm{C} 10$ \\
\hline F4 & $\begin{array}{l}\text { Hectares conducive to estab. from } \\
\text { Geophyto. Model }\end{array}$ & $\begin{array}{l}\text { Empirical } \\
\text { distrib. }\end{array}$ & $2,000,1,001,000$ & 0 & 0 & 0 \\
\hline F5 & Total hectares of winter wheat & Normal & $25,627,667,188,822$ & $247,700,868,192$ & $903,000,65,784$ & $120,244,27,747$ \\
\hline $\mathrm{C} 12$ & $\%$ of wheat land conducive to estab. & & F4 / F5 & F4 / F5 & F4 / F5 & $\mathrm{F} 4 / \mathrm{F} 5$ \\
\hline $\mathrm{C} 13$ & Spores arriving at land conducive to estab. & & $\mathrm{C} 12 * \mathrm{C} 11$ & $\mathrm{C} 12 * \mathrm{C} 11$ & $\mathrm{C} 12 * \mathrm{C} 11$ & $\mathrm{C} 12 * \mathrm{C} 11$ \\
\hline C14 & Spores per conducive hectare & & $\mathrm{C} 13 / \mathrm{F} 5$ & C13/F5 & C13/F5 & C13/F5 \\
\hline $\mathrm{T} 1$ & Spores per hectare disease threshold & Constant & $86,000,000$ & $86,000,000$ & $86,000,000$ & $86,000,000$ \\
\hline $\mathrm{C} 15$ & Net spores per hectare & & $\mathrm{T} 1-\mathrm{C} 15$ & $\mathrm{~T} 1-\mathrm{C} 15$ & $\mathrm{~T} 1-\mathrm{C} 15$ & $\mathrm{~T} 1-\mathrm{C} 15$ \\
\hline C16 & Threshold exceeded? & $\begin{array}{l}\text { If } \mathrm{C} 15>=0 \\
\text { If } \mathrm{C} 15<0\end{array}$ & $\begin{array}{l}\text { Potential estab. } \\
\text { Estab. unlikely }\end{array}$ & $\begin{array}{l}\text { Potential estab. } \\
\text { Estab. unlikely }\end{array}$ & $\begin{array}{l}\text { Potential estab. } \\
\text { Estab. unlikely }\end{array}$ & $\begin{array}{l}\text { Potential estab. } \\
\text { Estab. unlikely }\end{array}$ \\
\hline
\end{tabular}


butions of model input data; $\mathrm{P}$ designates a probability function; and $\mathrm{C}$ designates a mathematical calculation. Additionally, most functions throughout the model are intuitively described as percentages to simplify reader comprehension, although in reality they were handled mathematically as probabilities.

F1: Total annual tonnage of wheat to a country from all U.S. origins. F1 was based on the total annual tonnage of wheat exported to a country for a period of time, derived from historical data provided by USDA Grain Inspection, Packers, and Stockyards Administration (GIPSA) or from the wheat industry. A normal distribution was used. The distribution is truncated to prevent values below the minimum recorded tonnage shipped (negative values) for the specific importing country evaluated.

F2: Proportion of annual tonnage of wheat from different U.S. export terminals. We assumed that wheat imported annually by a country could originate from any U.S. port facility throughout the importing period (1 year). Because of differences in export tonnage, prevalence of dwarf bunt, and available statistical data from U.S. Gulf and PNW export terminals, two separate distributions (F2G and F2P, respectively; Fig. 3) were used in the model to determine F2, the total annual wheat tonnage exported. The annual tonnage of wheat exported to a country was derived from historical data provided by GIPSA.

F2P: Share of wheat shipped from PNW terminals. F2P represents the annual percentage of the total wheat tonnage shipped from PNW export terminals, with a most likely value of $50 \%$. Industry experts stated that the proportion of wheat shipped from the PNW could range from 30 to $70 \%$ annually. A triangular distribution was used with a most-likely probability of 0.5 and a range of 0.3 to 0.7 .

F2G: Share of wheat shipped from Gulf terminals. F2G is the complement of the triangular distribution of $\mathrm{F} 2 \mathrm{P}$ and is defined as: $\mathrm{F} 2 \mathrm{G}=1-\mathrm{F} 2 \mathrm{P}$.
C1P: Total wheat shipped from PNW (metric tons per year): $\mathrm{C} 1 \mathrm{P}=\mathrm{F} 1 \times \mathrm{F} 2 \mathrm{P}$.

C1G: Total wheat shipped from Gulf (metric tons per year): $\mathrm{C} 1 \mathrm{G}=\mathrm{F} 1 \times \mathrm{F} 2 \mathrm{G}$.

F3P: TCK teliospores per ton of PNW wheat $(20,000 \times$ TCK count $/ 50 \mathrm{~g})$. F3P is an empirical distribution function derived from actual data from a 1994 to 2004 study of $T$. contraversa contamination levels in PNW wheat export shipments summarized in Table 2 (T. B. Whitaker and G. L. Peterson, unpublished data). Data are based on analysis of 6,767 50-g whole-ship wheat composite samples. The validity of using a whole-ship composite export sample as representative of the uniformity of spore dispersal in the export lot is supported by a separate USDA study (42). Composite samples, prepared for official grading and representative of export shipments, were used for the dwarf bunt analysis. Although some wheat exports, such as those to Mexico, are delivered by railcar and truck, it was assumed that the spore concentrations were similar to those obtained from marine export terminals because grain is handled similarly until loaded into the export conveyance. The method of sample analysis was a modification of Mathre and Johnston (22) in which a 50-g seed sample is washed in $100 \mathrm{ml}$ of detergent water, the wash filtered through a 50- $\mu \mathrm{m}$ mesh nylon screen, the filtrate centrifuged to concentrate the debris and transferred to microscope slides, and the total number of teliospores in the sample debris determined by light microscopy. The method used to identify TCK teliospores was based on general morphology and use of reticulum depth to differentiate $T$. contraversa from T. tritici (if $\geq 0.95 \mu \mathrm{m}=T$. contraversa). This method does not differentiate TCK from a number of common grass smuts $(T$. fusca and T. bromi), which, although common, generally occur in very low numbers in export wheat shipments (G. L. Peterson, personal observation). From a trade perspective, the risk of misidentifying a grass smut becomes the exporters' risk for possible commodity rejection. The effect on this risk assessment model is an overestimation of $T$. contraversa contamination levels resulting in a slight elevation of projected risk associated with this node of the model.

F3G: TCK teliospores per ton of Gulf wheat $(20,000 \times$ TCK count $/ 50 \mathrm{~g})$. F3G is an empirical distribution function derived from actual data from a single 1991 study (G. L. Peterson, unpublished data) to identify and quantify Tilletia species occurring in Gulf wheat export shipments. Because of transportation costs, wheat originating from dwarf bunt affected regions of the PNW rarely moves to Gulf export terminals; therefore, $T$. contraversa teliospores are seldom found in Gulf wheat shipments. For this reason, the costly 10-year study used to provide the data used in F3P was not conducted for Gulf wheat shipments. The available data related to $T$. contraversa teliospore levels in Gulf exports are summarized in Table 2. Data are based on analysis of $52850-\mathrm{g}$ whole-ship wheat composite samples.

C2P: Calculated number of teliospores from PNW shipments, annually: $\mathrm{C} 2 \mathrm{P}=\mathrm{C} 1 \mathrm{P} \times \mathrm{F} 2 \mathrm{P}$.

C2G: Calculated number of teliospores from Gulf shipments, annually: $\mathrm{C} 2 \mathrm{G}=\mathrm{C} 1 \mathrm{G} \times \mathrm{F} 2 \mathrm{G}$.

C3: Calculated number of teliospores in U.S. wheat shipments, annually: $\mathrm{C} 3=$ $\mathrm{C} 2 \mathrm{P}+\mathrm{C} 2 \mathrm{G}$.

P1: Percent grain used for milling. P1 is the annual percentage of teliospores in grain entering the mill. Wheat milling experts in some countries estimate that up to $10 \%$ of domestic grain is lost during and after unloading but prior to entering the mill. However, imported grain is handled with far greater care than domestic grain, and therefore, estimated losses are reduced to approximately $2 \%$ annually. Based on these range estimates, a beta distribution with the parameters 6 and 2 (related to the mean and variance) was used to represent the P1 values ranging from 0.9 to 0.98 . The parameters were chosen to represent a situation in which values were skewed to the right since imported U.S. wheat is of

Table 2. Frequency of contamination levels of Tilletia contraversa teliospores found in 50-g whole-ship wheat composite samples taken from all export shipments leaving U.S. Pacific Northwest ports from 1994 until 2004 and southern U.S. ports in 1991

\begin{tabular}{|c|c|c|c|c|c|c|}
\hline \multirow[b]{2}{*}{ Spore count/50 g } & \multicolumn{3}{|c|}{ Wheat ships loaded U.S. Pacific Northwest ports } & \multicolumn{3}{|c|}{ Wheat ships loaded U.S. Gulf ports } \\
\hline & Frequency $(\mathbf{N})$ & $\%$ & CUM \% & Frequency $(\mathbf{N})$ & $\%$ & CUM \% \\
\hline 0 & 409 & 6.0 & 6.0 & 462 & 87.5 & 87.5 \\
\hline $1-10$ & 449 & 6.6 & 12.6 & 59 & 11.2 & 98.7 \\
\hline $11-50$ & 908 & 13.4 & 26.0 & 5 & 0.9 & 99.6 \\
\hline $51-100$ & 1,146 & 16.9 & 42.9 & 2 & 0.4 & 100.0 \\
\hline $101-500$ & 2,518 & 37.2 & 80.1 & 0 & 0.0 & 100.0 \\
\hline $501-1,000$ & 606 & 9.0 & 89.1 & 0 & 0.0 & 100.0 \\
\hline $1,001-2,500$ & 437 & 6.5 & 95.6 & 0 & 0.0 & 100.0 \\
\hline $2,501-5,000$ & 160 & 2.4 & 98.0 & 0 & 0.0 & 100.0 \\
\hline $5,001-10,000$ & 70 & 1.0 & 99.0 & 0 & 0.0 & 100.0 \\
\hline $10,001-30,000$ & 43 & 0.6 & 99.7 & 0 & 0.0 & 100.0 \\
\hline $30,001-60,000$ & 12 & 0.2 & 99.8 & 0 & 0.0 & 100.0 \\
\hline$>60,000$ & 9 & 0.1 & 100.0 & 0 & 0.0 & 100.0 \\
\hline
\end{tabular}


higher commercial value and therefore would be handled with greater care.

P2: Percent teliospores spread by grain handling. P2 is the percentage of teliospores that become airborne during movement of grain from port, railcar, or trucking terminal to unloading at the mill. The TCK-risk model assumes that all teliospores are airborne. Based on expert information and industry records showing grain losses on the way to the mill, and therefore teliospore loss of equal proportion, $\mathrm{P} 2$ is estimated to be 0.25 to 0.305 . Because no value was determined to be any more likely to occur, the probability was described as a uniform distribution with a range of 0.0025 to 0.003 .

P3: Percent teliospores released by milling. P3 is the percentage of teliospores that become airborne during the milling process and escape through the mill's air filtration system to the outside environment. To evaluate the effect of the milling process on $T$. contraversa spores, Bechtel et al. (3) conducted a study at the Kansas State University with the Department of Grain Science and Industry Pilot Mill. Heavily contaminated white wheat was mixed with uncontaminated hard red winter wheat to produce a highly contaminated 60-bushel lot of wheat. The wheat was then cleaned and milled under normal settings, and samples were taken from different points throughout the milling stream and from the mill air filters at the completion of the run. The numbers of teliospores in these samples were determined.

Based on the work of Bechtel et al. (3), $1.8 \%$ of the teliospores entering the mill are trapped in the house filters. The filter efficiency is rated at $96 \%$; therefore, $4 \%$ of $1.8 \%$ of the teliospores entering the filter may escape. Because occasionally filters are damaged or temporarily removed, it was estimated that up to $10 \%$ of the spores trapped in the dust filters could escape the mill filter system annually. A beta distribution with the parameters 2 and 18 was used to represent the $\mathrm{P} 3$, yielding a mean of 0.0068 with a median of 0.0203 and a range of 0.002 to 0.0295 . This is highly skewed to the left, but $25 \%$ of the values are between 0.0022 and 0.0075 and half between 0.002 and 0.00203 . The parameters were chosen to represent a situation in which values at the lower end of this range were more likely to occur than values near the higher end, assuming filter failure is not a common event.

C4: Probability of teliospores spreading to field by grain handling: $\mathrm{C} 4=\mathrm{P} 2+$ P3.

P4: Percent teliospores that survive to millfeed. P4 is the annual percentage of teliospores that survive the milling process and accumulate in the millfeed. Bechtel et al. (3) showed that 95 to $97 \%$ of the teliospores that survived milling were found in the cleanings, house filter dust, and ento- leter scourer-aspirator material. A few spores were found in the bran and shorts. No spores were detected in the flour or wheat red dog. These by-products and cleanings were combined to form the millfeed in which $21.1 \%$ of the total teliospores in the original grain entering the mill were concentrated. In the Bechtel et al. experiments (3), although the conclusions of both experiments were the same, the number of teliospores recovered was greater in the second experiment than the first. For the purpose of the TCK-risk Model, to conservatively compensate for the skewness of these two studies, a beta distribution with the parameters 4 and 2 was used to represent the $\mathrm{P} 4$ values ranging from 0.1 to 0.3 to reflect a situation in which values at the higher end of this range were more likely to occur than values near the lower end.

P5: Percent teliospores spread to fields by millfeed handling. P5 is the annual percentage of teliospores that are spread to a field by millfeed handling, specifically through transport and unloading from the mill to the livestock. According to industry data, millfeed loss in handling and transportation is estimated between 0.1 to $1.0 \%$ annually. No specific data were available within the actual range; therefore, a uniform distribution with a range of 0.001 to 0.01 was used.

P6: Percent teliospores fed to livestock. P6 is the annual percentage of teliospores fed to livestock through ingestion of millfeed. This distribution is estimated from the millfeed usage records of the importing country. Millfeed is often used in aquaculture and pet food as well as for cattle, chicken, and pig feed. Based on historical records, a beta distribution with the parameters 4 and 2 was used to represent the P6 with the range determined by data available for each country. The beta distribution was used to represent a situation in which values at the higher end of this range (greater quantity to livestock) were more likely to occur than values near the lower end.

P7: Percent teliospores surviving in manure. P7 is the annual percentage of teliospores that pass through the digestive tract of livestock and survive in the manure. Limited research $(31,34)$ suggests ranges of 12 to $64 \%$ of the teliospores ingested by chickens and 32 to $36 \%$ ingested by cattle survive. Little information is available on survival in pig manure. Based on the limited available data, the highest percentage of teliospore survival reported from the two studies was used to describe the probability as a uniform distribution with a range of 0.3 to 0.7 .

P8: Percent teliospores spread to wheat fields in manure. P8 is the annual percentage of teliospores spread on wheat fields by manuring. It was conservatively estimated that annually, only 40 to $60 \%$ of manure is spread on wheat fields. The remaining portion is assumed to be dispersed to other crops. The probability was described as a uniform distribution with a range of 0.40 to 0.60 . No separate node for secondary spread of spores from nonwheat fields to a winter wheat field (or the movement out of a wheat field) was included in the model. Although no data are available to develop a distribution for this, it was assumed risk of teliospores moving into a wheat field would be equal to the risk of movement out.

C5: Teliospores spread to fields by livestock consuming millfeed. $\mathrm{C} 5$ is the yearly percentage of teliospores that could potentially be deposited in a field through the feeding of livestock with contaminated millfeed: $\mathrm{C} 5=\mathrm{P} 6 \times \mathrm{P} 7 \times \mathrm{P} 8$.

C6: Spores spread to wheat field by millfeed handling and feeding. C6 is the calculated annual percentage of teliospores spread to the field after milling. This is derived from the probability distributions of teliospores in the millfeed (P4), teliospores spread by millfeed handling (P5), and teliospores spread into the field by livestock via manure (C5): $\mathrm{C} 6=\mathrm{P} 4 \times(\mathrm{P} 5$ $+\mathrm{C} 5$ ).

C7: Spores spread to wheat field per year. C7 is the calculated annual percentage of spores spreading to the wheat field by grain handling $(\mathrm{C} 4)$ and through the millfeed (C6): $\mathrm{C} 7=\mathrm{C} 4+\mathrm{C} 6$.

C8: Total teliospores from milling. $\mathrm{C} 8$ is the annual percentage of teliospores per year that might be diverted from the milling process and potentially arrive in a field. This is calculated using the probability distribution of teliospores unloaded at the mill (P1) and the percent teliospores that survive the milling process and could be deposited in a field (C7): $\mathrm{C} 8=\mathrm{P} 1 \times \mathrm{C} 7$.

P9: Grain diverted to planting. $\mathrm{P} 9$ is the annual percentage of teliospores that do not enter the milling system, but are diverted in transport to the mill. Because there are no data to estimate the varying percentages of wheat that are diverted from the mill as seed for planting, animal feed, or human consumption, the model considers that all grain diverted is planted, this being the highest biological risk and thus the most conservative perspective. P9 is the complement of probability distribution P1: P9 = $1-\mathrm{P} 1$

P10: Percent teliospores spread to wheat field. P10 represents the annual percentage of teliospores transported to the field on contaminated seed and planted. Because P9 assumes that all grain diverted will be planted, probability P10 is assumed to be 1.0 .

C9: Percent teliospores from grain diverted to planting. $\mathrm{C} 9$ defines the total percentage of teliospores per year which could potentially be diverted directly to the field by planting. It is calculated from the probability distributions of grain diverted for planting (P9) and teliospores spread in wheat $(\mathrm{P} 10): \mathrm{C} 9=\mathrm{P} 9 \times \mathrm{P} 10$. 
C10: Teliospore dispersal into wheat fields. $\mathrm{C} 10$ is the annual percentage of teliospores per year that could potentially be dispersed into a wheat field from the milling process, millfeed, and diverted grain. It is calculated based on the probability distributions of teliospores from the milling process (C8) and teliospores diverted from the mill and planted (C9): $\mathrm{C} 10$ $=\mathrm{C} 8+\mathrm{C} 9$.

C11: Total number of teliospores dispersed into fields. $\mathrm{C} 11$ is the total number of teliospores that could be deposited on wheat fields annually, with an assumption of a uniform distribution. It is calculated based on the total number of teliospores arriving in a country annually (C3) and the percentage of those teliospores dispersed to wheat fields $(\mathrm{C} 10)$ : $\mathrm{C} 11=\mathrm{C} 10 \times \mathrm{C} 3$.

F4: Hectares of potentially conducive environment. F4 is the number of hectares of potentially conducive environment. Based on the results obtained from the TCK-GM, a cumulative distribution function was used with a range of hectares reflecting the yearly variation in hectares that meet the dwarf bunt-conducive environmental parameters. For the purpose of this scenario analysis, the TCK-GM used Introduction scenario previously described.

F5: Total hectares in wheat. F5 is the number of hectares in wheat production annually. For a given country, annual data from historical records were used to construct a normal distribution.

C12: Percent wheat land conducive to introduction. $\mathrm{C} 12$ is the percentage of potentially conducive hectares per year, based on the number of conducive-hectares identified by the TCK-GM and the total hectares in wheat production. It is determined using the number of dwarf buntconducive wheat hectares (F4) and the total number of hectares in wheat (F5): $\mathrm{C} 12=\mathrm{F} 4 / \mathrm{F} 5$.

C13: Total spores arriving on all conducive hectares. $\mathrm{C} 13$ is the total number of teliospores that arrive on all conducive hectares of wheat annually based on the total number of teliospores (C11) dispersed to wheat fields of a given country and the percentage of conducive hectares (C12): $\mathrm{C} 13=\mathrm{C} 11 \times \mathrm{C} 12$.

C14: Teliospores per potentially conducive hectare. $\mathrm{C} 14$ calculates the total number of teliospores dispersed onto a conducive hectare per year. This is determined by the total number of teliospores reaching conducive wheat fields $(\mathrm{C} 13)$ and wheat hectares in the conducive environment (F4): $\mathrm{C} 14=\mathrm{C} 13 / \mathrm{F} 4$.

T1: Teliospores per hectare: Disease threshold constant. The values used to establish the disease threshold level $(\mathrm{T} 1=$ $86,000,000$ teliospores per hectare) were derived from a replicated 3-year ARS study (12) of the relationship between soilborne and seedborne inoculum density and the incidence of dwarf bunt of wheat. The study was conducted at two sites near
Logan, UT, and one in Bozeman, MT, in fields with a history of frequent annual high disease incidence. Fields were fumigated with methyl bromide under tarp to eliminate the existing $T$. contraversa teliospore populations. To prevent the movement of teliospores from outside the fumigated fields in rain runoff, or the dispersal of teliospores out of our experimental plots, plots were surrounded with plywood fences. Based on study results, it was estimated that even under a highly conducive environment, it is unlikely that disease will occur until surface inoculum levels approach $860,000,000$ teliospores/hectare. To provide an additional level of safety, a level 10 times lower was chosen as the disease threshold constant, 86,000,000 teliospores per hectare (T1). The model assumes that at this level, dwarf bunt is unlikely to occur even under favorable environmental conditions.

C15: Net teliospores. $\mathrm{C} 15$ is the total number of teliospores per dwarf bunt con-

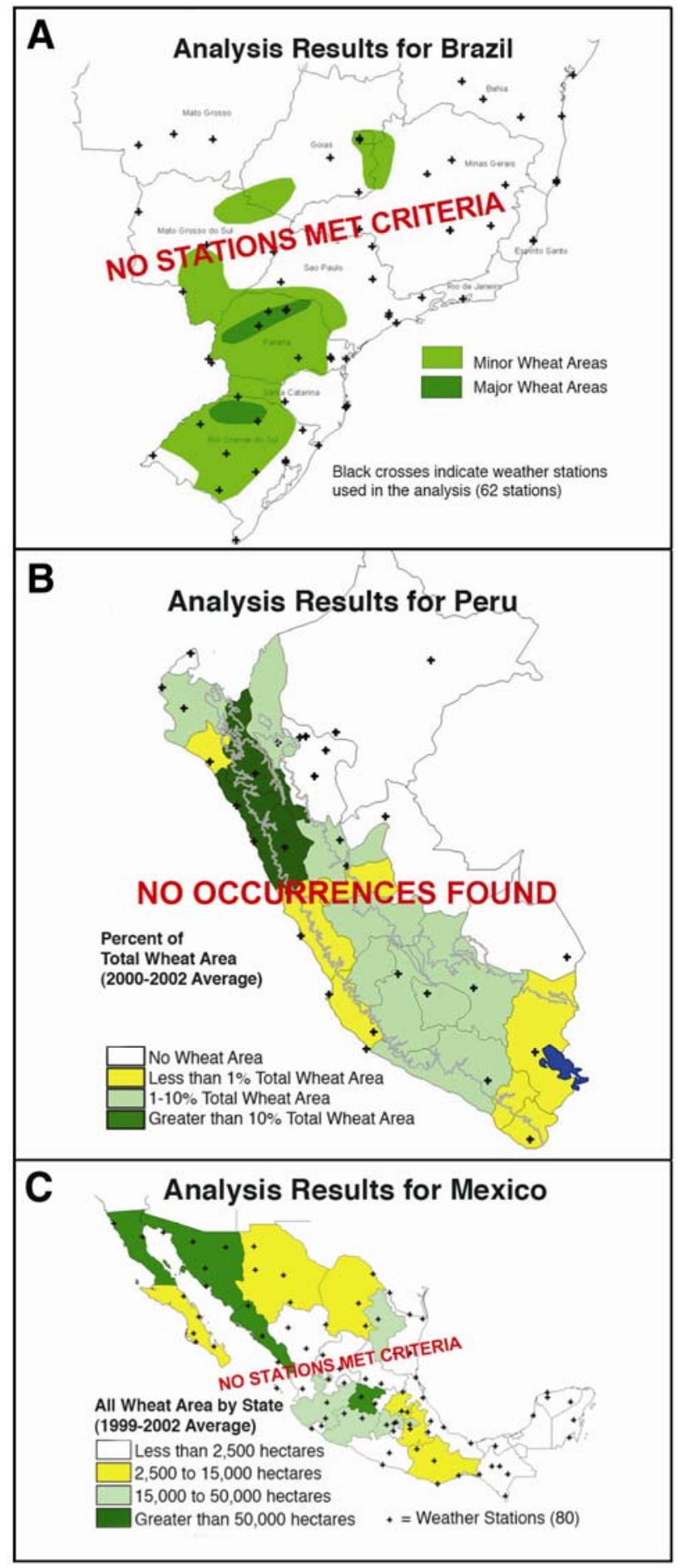

Fig. 5. Location of wheat growing areas and distribution of weather stations used in the Geophytopathological Model for A, Brazil, B, Peru, and C, Mexico. No conditions favorable to dwarf bunt establishment were identified. 
ducive wheat hectare in excess of the Disease Threshold Constant determined from the total number of teliospores per conducive hectare (C14) and the Disease Threshold Constant (T1): C15 = C14 - T1.

C16: Threshold exceeded. C16 determines if the Disease Threshold Constant is exceeded and sufficient numbers of teliospores are available to allow for the introduction of dwarf bunt in a conducive environment with a susceptible host. If $\mathrm{C} 15>0$ then $\mathrm{C} 16=1$ (introduction is likely). If $\mathrm{C} 15<0$ then $\mathrm{C} 16=0$ (no likelihood of introduction).

\section{TCK-Risk Model Analyses for Brazil, Peru, Mexico, and China}

The country-specific TCK-risk model inputs for the Introduction scenario for importing U.S. milling wheat into Brazil, Peru, Mexico, and China are presented in Table 1. F1 is the annual tonnage of wheat

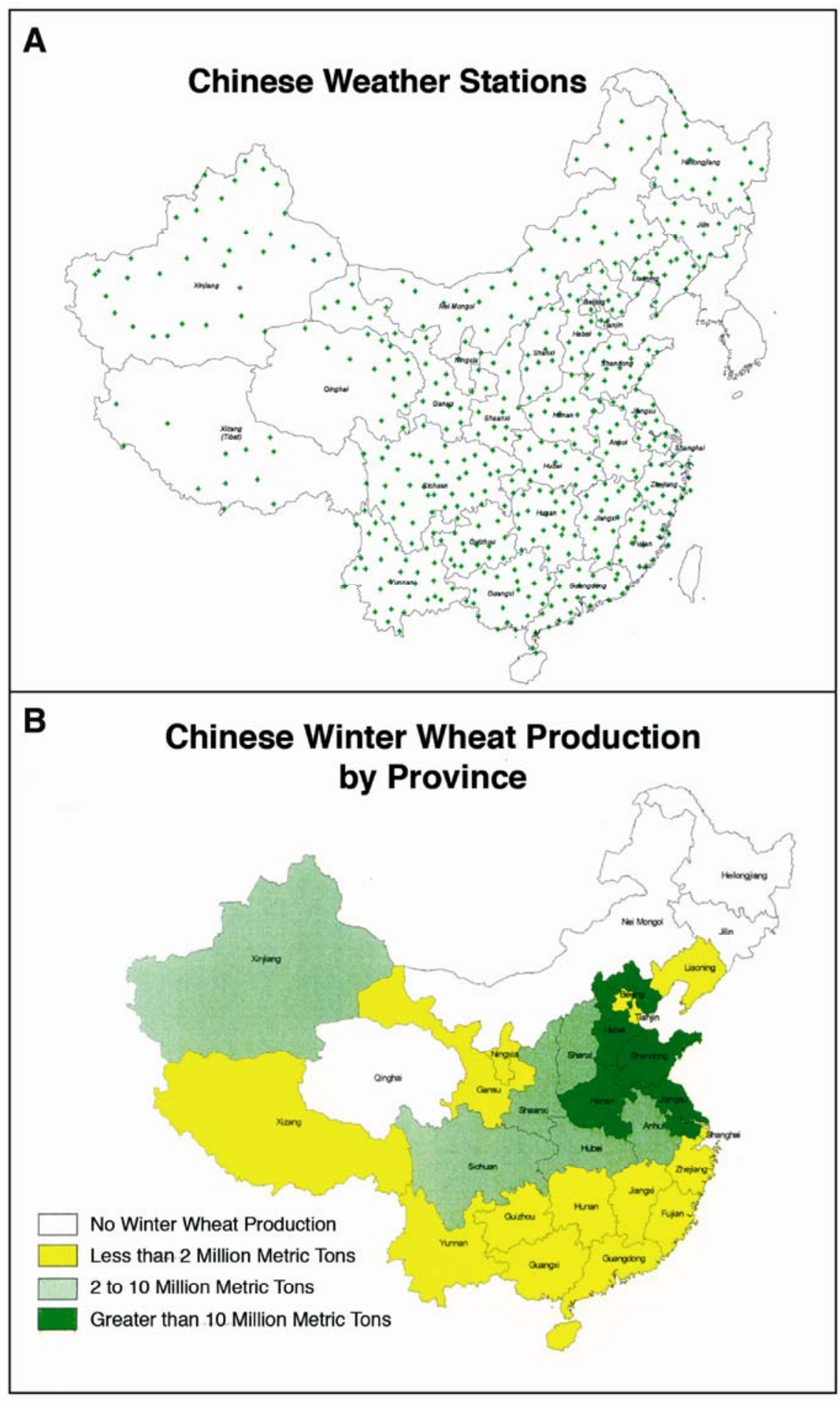

Fig. 6. A, Distribution of Chinese weather stations used in the Geophytopathological Model analyses to identify regions favorable to the introduction of dwarf bunt of wheat. B, Distribution of winter wheat planting in the People's Republic of China. exported to Brazil, Peru, Mexico, and China based on historical records of 15 , 41,15 , and 11 years, respectively. Shown are the mean, standard deviation, and ranges of the data by country. This normal distribution was truncated to prevent the occurrence of values below the least tonnage of wheat shipped. F4 is the number of hectares of potentially conducive environment. Climatic data for a period of 15 years were obtained from $62,29,85$, and 482 weather stations distributed across Brazil (Fig. 5A), Peru (Fig. 5B), Mexico (Fig. 5C), and China (Fig. 6A), respectively. F5 is the number of hectares in wheat production annually. The table shows the mean of number of hectares and a standard deviation of hectares for this normal distribution derived from data obtained from the annual wheat production records of the four countries over 15 years. Planting date inputs for the MODWHT3 wheat growth model were obtained from official records of each country.

Monte Carlo simulations were performed using both the Introduction and Yield Loss scenarios. One hundred thousand iterations of the model, each representing 1 year of importing wheat, were performed for all four countries using both scenarios. Model output was a probability derived from the number of times a number of $T$. contraversa teliospores likely to cause disease were introduced to a winter wheat field with environmental conditions favorable for supporting disease introduction or significant yield loss.

TCK-GM results for Brazil, Peru, and Mexico. Results obtained from the TCKGM for Brazil, Peru, and Mexico showed no areas that met the minimum requirements for potential disease introduction or significant yield loss. Therefore, $\mathrm{F} 4=0$, which suggests that it would be unlikely that importing U.S. milling wheat containing teliospores of $T$. contraversa would lead to the establishment of dwarf bunt because the environmental conditions favorable for disease are absent. Using environmental data from their weather stations, the TCK-GM was effective in convincing these trading partners that the risk of introducing dwarf bunt into their wheat growing regions was minimal.

TCK-GM results for PRC. China's winter wheat production regions are shown in Figure 6B. Results of the TCK-GM evaluations for the Introduction and Yield Loss scenarios are presented in Figure 7A and $\mathrm{B}$, respectively. In both panels, as with TCK-GM results for the United States (Fig. 4B), spring wheat growing regions were also identified because of the existence of continuous snow cover in northeastern PRC.

TCK-GM results for the Introduction scenario generated a cumulative distribution function (F4) with a range of 2,000 to $1,001,000$ dwarf bunt-conducive hectares. Areas identified were limited to winter 
wheat growing areas in Gansu, Guizhou, Hubei, Hunan, Shanxi, Xinjiang, and Sichuan provinces where $3.8 \%$ of winter wheat hectares had conditions conducive for dwarf bunt introduction at least 1 year in the 15 years examined. In only $1 \%$ of the potentially conducive hectares, limited to Guizhou, Sichuan, and Xinjiang provinces, did conditions that might perpetuate the disease occur in more than $25 \%$ of the years examined (Fig. 6A).

TCK-GM results for the Yield Loss scenario generated a cumulative distribution function (F4) with a range of 2,000 to 350,000 dwarf bunt-conducive hectares, which accounts for $1.3 \%$ of the total winter wheat hectares in the PRC. The identified regions were limited to small areas of Gansu, Shanxi, and Xinjiang provinces which met the condition of 60 or more days of continuous snow cover at least once in the 15 years evaluated. In this analysis, only $0.5 \%$ of the hectares in the province of Xinjiang were identified as having disease-conducive conditions occurring in more than $25 \%$ of the 15 years examined.

\section{Monte Carlo Simulations of TCK- Risk Model Scenarios for PRC}

Introduction scenario for PRC. In the 100,000 iteration simulation, there were 50 incidences in which the spore loading in China exceeded the 86 million spores per hectare threshold for introduction. Thus, it was concluded that the probability of successful introduction is 0.0005 . A summary of the teliospore counts per hectare are presented in Table 3. The maximum count observed was 413,196,700 teliospores per hectare. Only 5\% of the Monte Carlo iterations of this scenario had spore counts in excess of 340,864 per hectare.

Yield Loss scenario for PRC. The probability of exceeding the spore threshold in an area conducive to yield loss occurred in 60 of the 100,000 Monte Carlo iterations. Thus, it was determined that the probability of establishment is 0.0006 . Spore counts per hectare observed in the simulation are summarized in Table 3 . Only $5 \%$ of the Monte Carlo iterations of this scenario had spore counts in excess of 339,505 per conducive hectare.

Sensitivity, as determined by rank order correlation, identified that F3P: $T$. contraversa teliospores per ton of PNW wheat, had values that correlated $(R=$ $0.894)$ most highly with those of the target variable (i.e., spores per conducive hectare); the next most highly correlated input variable was F1: Annual tonnage of wheat to China from all U.S. origins $(R=0.357)$. All other input variables had substantially smaller correlations $(R<0.05)$ with the target variable. Therefore, the primary factors that control whether dwarf bunt would likely establish under favorable environmental conditions is the level of $T$. contraversa teliospores in the shipment and the quantity of grain imported.
In order to determine if 100,000 iterations were sufficient and the estimated probabilities stabilized, the Monte Carlo simulation of the Introduction scenario was performed 10 times, and confidence interval was determined. These results were compared with that of an additional simulation with one million iterations. Results gave a mean number of positives (introductions) of $0.098 \%$ with a standard error of 0.0023 and a $95 \%$ confidence interval of 0.093 to $0.103 \%$, confirming that the probabilities have stabilized. The mean percentage of positives obtained when the number of iterations was increased to $1,000,000$ was $0.1035 \%$, within the confidence interval of the 100,000 simulations.

To demonstrate the utility of the TCKrisk model, three new scenarios were proposed and applied to the PRC analysis. We referred to these as Scenario 3: All wheat shipped from the PNW; Scenario 4: Increase in wheat imports by PRC; and Scenario 5: Bio-accumulation of teliospores over 10 years.

Scenario 3. If all the wheat exported to the PRC comes from the PNW, it is likely teliospore levels in the model would be greater because $T$. contraversa is not commonly observed in Gulf wheat shipments. Hence, a scenario was developed in which

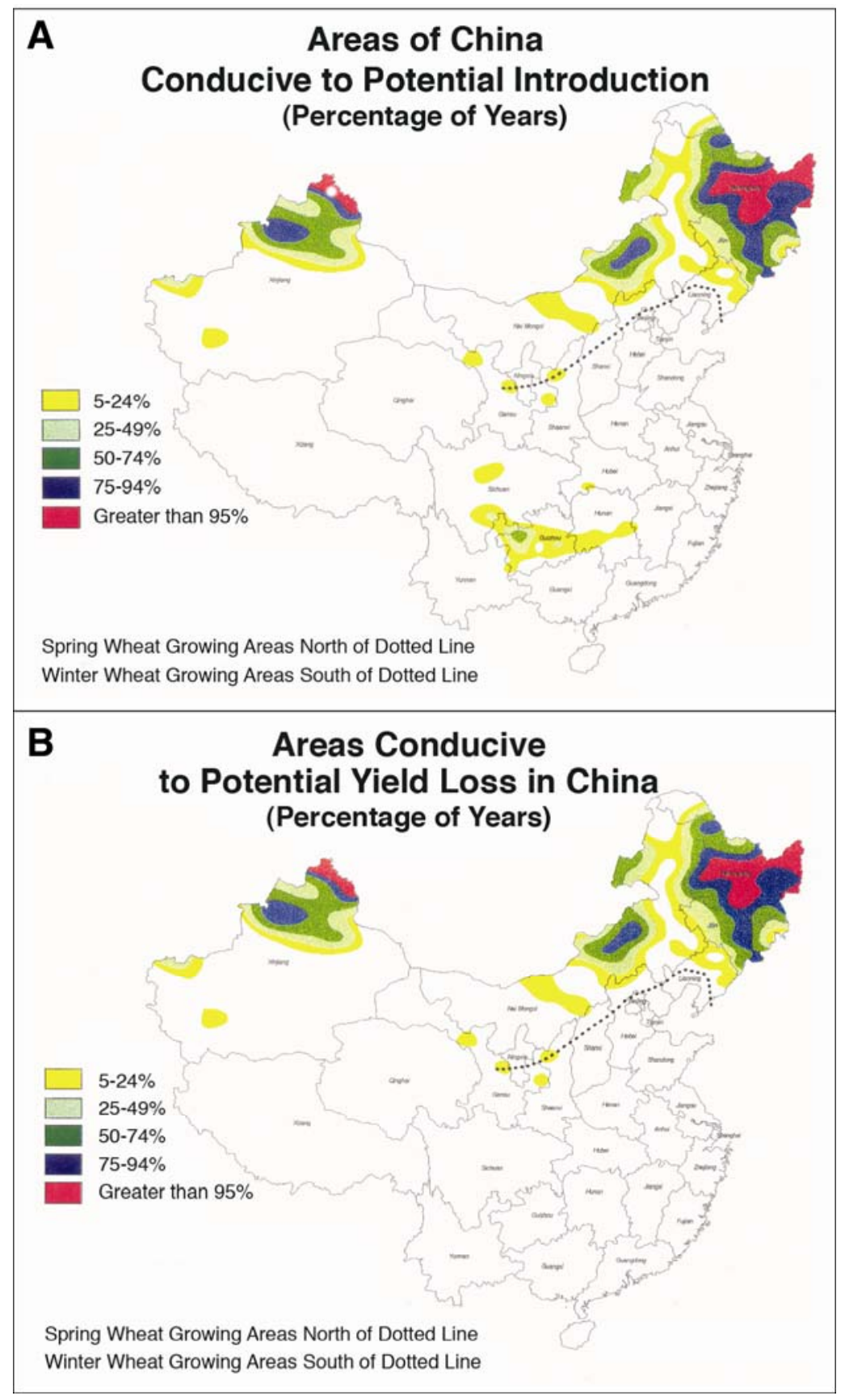

Fig. 7. Results of Geophytopathological Model analysis of the People's Republic of China to identify locations and annual frequency of dwarf bunt-conducive conditions for both the A, Introduction scenario, and B, Yield Loss scenario. 
all the export wheat came from the PNW. The only deviation from the Introduction scenario is that the TCK-risk model node for F2P: Share of wheat shipped from PNW, was changed from a triangular distribution to a fixed value equal to one. This assured that all wheat shipped would come exclusively from PNW. Results determined that importing wheat only from the PNW would result in a probability for introduction of 0.001. A summary of the spore counts is presented in Table 4.

Scenario 4. In this scenario, the PRC would increase imports to as much as 30 million tons per year (double the current highest year). This increased tonnage implies an increased exposure to T. contraversa teliospores. To investigate the potential impact of such a change in trade, the normal distribution for F1: Annual tons of wheat to the PRC from all US origins, was changed to a single value, 30 million tons, in order to consider the maximum risk. Results of the Monte Carlo simulations estimate a probability for introduction of 0.0006 based on exceeding the disease threshold 62 times in 100,000 iterations. A summary of spore counts is presented in Table 4.
Scenario 5. The build-up of spores over 10 years (Bio-accumulation) scenario assumes that teliospores would accumulate in the soil over 10 years of importing. This assumes that in each year the soil was cultivated for planting, distributing the spores on the surface into the soil, and that $10 \%$ of the previous year's spore load remained on the surface where it could infect. This amount was added to the total number of spores arriving in a wheat field the following year, and the process repeated for the next 8 years. In the 10 years examined, representing a total of $1,000,000$ iterations of the TCK-risk model, the threshold was exceeded each year (range: 0.001 to 0.0004). For each year, the estimated probabilities of introduction are presented in Table 5. We considered this an especially rigorous evaluation. The $10 \%$ carryover of viable teliospores on the soil surface is very conservative when considering that the life expectancy of free spores in the soil is only 1 to 5 years (14). Furthermore, if we assume that agricultural practices are efficient, during field cultivation teliospores would be distributed throughout the soil to a depth of $20 \mathrm{~cm}$, and less than $1 \%$ rather

Table 3. Count summaries after Monte Carlo 100,000 iterations of the Tilletia contraversa-risk model showing the simulated number of teliospores per hectare escaping the milling process and ending on a hectare of land in China conducive to the development of dwarf bunt of wheat using both the Introduction and Yield Loss model scenarios

\begin{tabular}{lcc}
\hline & \multicolumn{2}{c}{ Spore count per conducive wheat hectare } \\
\cline { 2 - 3 } & Introduction scenario $^{\mathbf{a}}$ & Yield Loss scenario $^{\mathbf{b}}$ \\
\hline Minimum spore count per hectare & 1 & 2 \\
Maximum spore count per hectare & $413,196,700$ & $405,332,400$ \\
Mean spore count per hectare & 209,542 & 216,685 \\
5th percentile spore count per hectare & 217 & 218 \\
95th percentile spore count per hectare & 340,864 & 339,505 \\
\hline a Sixty days of continuous snow cover or 42 or more days of precipitation while surface soil \\
temperatures stayed between -2 and $10^{\circ} \mathrm{C}$ during wheat tillering. \\
b Sixty days of continuous snow cover during wheat tillering.
\end{tabular}

Table 4. Summary results of Tilletia contraversa-risk model scenarios for the effects of China importing all wheat from Pacific Northwest (PNW) export terminals and those of increasing annual imports to 30 million tons

\begin{tabular}{lrc}
\hline & \multicolumn{2}{c}{ Spore count per conducive wheat hectare } \\
\cline { 2 - 3 } & $\begin{array}{c}\text { All wheat } \\
\text { from PNW }\end{array}$ & $\begin{array}{c}\text { Increased export } \\
\text { tonnage }\end{array}$ \\
\hline Minimum spore count per hectare & 1 & 1 \\
Maximum spore count per hectare & $654,897,600$ & $437,467,100$ \\
Mean spore count per hectare & 412,085 & 203,722 \\
5th percentile spore count per hectare & 301 & 215 \\
95th percentile spore count per hectare & 680,565 & 337,572 \\
\hline
\end{tabular}

than $10 \%$ of the teliospores would remain at or near the soil surface (J. A. Hoffmann, Logan, UT, personal communication).

If results obtained in the U.S. TCK-GM validation are comparable with those obtained in the TCK-GM evaluation of the PRC, it is likely that those areas truly at risk for dwarf bunt introduction represent only a fraction of the winter wheat hectares identified by the TCK-GM evaluation. Expert opinion (J. A. Hoffmann, Logan, UT; D. E. Mathre, Bozeman, MT; and R. F. Line, Pullman, WA, personal communications) suggests that in order for measurable yield loss to occur, favorable weather conditions for dwarf bunt must occur at least once every 4 years. The TCK-GM evaluation of the Yield Loss scenario identified only $0.5 \%$ of China's winter wheat hectares as meeting that criterion.

The disease pathway for teliospore introduction into a wheat field with favorable disease conditions via direct massive spillage from a truck, rail car, or other conveyance was not incorporated in the TCK-risk model. No industry data or documentation was available to estimate such a distribution. However, in the case of the PRC, results obtained from the TCK-GM, the coastal locations of most of their mills handling imported wheat, and the economic nature of overland transportation would strongly suggest a low probability of such a spill occurring in a disease-conducive wheat field.

We note that the TCK-risk model was used by the USDA Foreign Agricultural Service in 1998 to successfully present a case for deregulation of $T$. contraversa by the PRC and resulted in the 1999 U.S./China Agricultural Cooperation Agreement that removed a 34-year embargo of U.S. wheat from PNW ports and established a tolerance level of 30,000 teliospores per $50 \mathrm{~g}$ whole-ship composite wheat sample.

The data set representing the level of teliospores in U.S. export shipments (F3P) used in that assessment was derived from the 2,714 whole-ship wheat composite samples collected between 1994 and 1998. Using that dataset, in no scenario did the Monte Carlo simulation detect a probability of introducing dwarf bunt into China, except in the Bio-accumulation scenario. Because the TCK-risk model was designed to be dynamic, we incorporated the new test results from an additional 4,053 ships sampled between 1998 and 2004 into the distribution data set (F3P). Within these new results we encountered one sample

Table 5. Bio-accumulation of $10 \%$ annual carryover (Scenario 5): Probability of teliospore levels exceeding the Tilletia contraversa-risk model threshold for disease introduction

\begin{tabular}{lcccccccccc}
\hline & Yr. 1 & Yr. 2 & Yr. 3 & Yr. 4 & Yr. 5 & Yr. 6 & Yr. 7 & Yr. 8 & Yr. 9 & Yr. 10 \\
\hline Exceedance frequency & 0.0009 & 0.0006 & 0.0004 & 0.0008 & 0.0008 & 0.0009 & 0.001 & 0.001 & 0.001 & 0.001 \\
\hline
\end{tabular}


with a teliospore count over 1 million per $50.0 \mathrm{~g}$ wheat ship composite sample that was likely due to a small fragment of sorus in the sample that exaggerated actual teliospore distribution in the ship. Although $99.9 \%$ of the samples tested contained less than 50,000 spores, this one high sample count, picked up in the 100,000 iterations of the Monte Carlo simulation, resulted in a minute probability of establishment by exceeding the disease threshold. Also noteworthy is that over the 10-year export ship sampling study, no sori were detected in any of the samples tested. This is likely due to both the disease management approaches used in the United States that have reduced levels of disease to trace amounts in commercial fields and breakage caused by the continual mixing and handling of grain en route to the export elevators. Additionally, USDA Directive FGIS 9180.47 and FGIS PN-00-7, "Examination of Grain for the Presence of TCK Spores", stipulates that the presence of a single bunt ball in a 1-kg sublot test sample would require rejection of the sublot for export.

Because of the U.S./China Trade Agreement, which established a 30,000 T. contraversa teliospores per 50-g composite wheat sample tolerance, the results obtained in this risk assessment do not reflect an increased risk to the PRC. The risk of importing wheat that contained enough spores to reach or exceed the threshold became unlikely because any U.S. ship with a sample testing over 30,000 teliospores per 50-g sample would not be permitted to go to the PRC. When the TCKrisk model was run after truncating the distributions for F3P and F3G (teliospores per shipment) above 30,000 teliospores per 50 -g sample, the $T$. contraversa threshold was never reached, even in the Bio-accumulation scenario. Notably, the cumulative frequency of $T$. contraversa contamination levels in the 10-year ship sampling study showed that $99.7 \%$ of the grain tested contained less than 30,000 teliospores per 50g sample.

From our perspective, the TCK-risk model has proven to be an effective means of communicating the likelihood of dwarf bunt introduction via the importation of contaminated milling wheat. Its dynamic versatility enables the use of scenario analysis for testing the effects of changes to import practices, as well as identifying potential mitigation actions and predicting their effectiveness. Although developed for U.S. exports, the final model is sufficiently versatile to be used by any country with endemic dwarf bunt wishing to export wheat.

The TCK-risk model was developed to evaluate quantitatively the interactive relationship between the host, environment, and pathogen, and to assess the level of risk associated with the importation of U.S. milling wheat. Its design and purpose is to provide regulators with a measurable scale in balancing the benefits achieved by the importation of the commodity with the possible phytosanitary risks associated with free trade. This concept recognizes that to realize the benefits of free trade, the philosophy of "zero risk" must be replaced with the modern approach of risk management and mitigation.

\section{Acknowledgments}

We acknowledge the support and participation of William M. Brown, Jr., Colorado State Univ., Fort Collins (deceased); Guillermo Fuentes-Davila, Instituto Nacional de Investigaciones Forestales y Agropecuarias, Sonora, Mexico; Roy Gingery, USDA ARS, Wooster, OH; James A. Hoffmann, USDA ARS (deceased); Lennart Johnsson, Swedish Univ. Agric. Science, Sweden; Robert Kahn, USDA APHIS (retired); Roland F. Line, USDA ARS, Pullman, WA (retired); William Dowler, Clemson Univ., Clemson, SC; Ian MacLatchy, Canadian Animal \& Plant Health Directorate, Ottawa, Canada; Don E. Mathre, Montana State Univ. (retired); H. C. Weltzien, Univ. of Bonn, Germany; Xaio Bing Yang, Iowa State Univ., Ames; Theodore Bownik, Archer Daniel, Midland, Kansas City, MO; James R. Jones, Univ. of Idaho, Moscow; John Pitchford, USDA Grain Inspection, Packers, and Stockyards Administration, Washington DC; Cina Radler, USDA, Foreign Agricultural Service, Washington DC; Rolli Sew, Kansas State Univ., Manhattan; Matthew Weimar and James Frahm, U.S. Wheat Assoc., Hong Kong, PRC and Washington DC, respectively; William W. Wilson, North Dakota State Univ., Fargo; and Charles Yoe, Greeley-Polhemus Group, Inc., Baltimore, MD. We also thank Claire E. Sansford, Department for Environment, Food and Rural Affairs Central Sci. Laboratory, UK; and Suresh B. Mathur, Danish Gov. Inst. of Seed Pathology for Developing Countries, Denmark, for their early critical reviews. We also thank Blair Goates, USDA ARS, Aberdeen, ID for Figure 1A.

\section{Literature Cited}

1. Anonymous. 1956. Snow Hydrology: Summary Report of Snow Investigations. North Pacific Division, Corps of Engineers, U.S. Army, Portland, OR, USA. Publ. no. EM 1110-23600.

2. Baylis, R. J. 1958. Studies of Tilletia contraversa, the cause of dwarf bunt of winter wheat. Can. J. Bot. 36:17-32.

3. Bechtel, D. B., Wilson, J. D., Eutace, W. D., Behnke, K. C., Whitaker, T. B., Peterson, G. L., and Sauer, D. B. 1999. Fate of dwarf bunt fungus teliospores during milling of wheat to flour. Cereal Chem. 76:270-275.

4. Coakley, S. M., Boyd, W. S., and Line, R. F. 1984. Development of regional models that use meteorological variables for predicting stripe rust disease on winter wheat. J. Climate Appl. Meteorol. 23:1234-1240.

5. Coakley, S. M., and Line, R. F. 1981. Quantitative relationships between climatic variables and stripe rust epidemics on winter wheat. Phytopathology 71:461-467.

6. Coakley, S. M., Line, R. F., and Boyd, W. S. 1983. Regional models for predicting stripe rust on winter wheat in the Pacific Northwest. Phytopathology 73:1382-1385.

7. Coakley, S. M., Line, R. F., and McDaniel, L. R. 1988. Predicting stripe rust severity on winter wheat using an improved method for analyzing meteorological and rust data. Phytopathology 78:543-550.

8. Coakley, S. M., McDaniel, L. R., and Line, R. F. 1988. Quantifying how climatic factors affect variation in plant disease severity: A general method using a new way to analyze mete- orological data. Climatic Change 12:57-75.

9. Conners, I. L., and Skoko, A. J. 1953. Bunt situation in winter wheat in Ontario. Can. J. Agric. Sci. 33:597-605.

10. Fenwick, H. S. 1974. Dwarf bunt of winter wheat. In: CES publ. no. 214 (Current Information Series). University of Idaho, Moscow, USA.

11. Goates, B. J. 1995. Dwarf bunt and common smut. Pages 12-25 in: Bunts and Smut Diseases of Wheat: Concepts and Methods of Disease Management. R. D. Wilcoxson and E. E. Sarri, eds. CIMMYT, Mexico City, Mexico.

12. Goates, B. J., and Peterson, G. L. 1999. Relationship between soilborne and seedborne inoculum density and the incidence of dwarf bunt of wheat. Plant Dis. 83:819-824.

13. Grey, W. E., Mathre, D. E., Hoffman, J. A. Powelson, R. L., and Fernadez, J. A. 1986. Importance of seedborne Tilletia contraversa for infection of winter wheat and its relationship to international commerce. Plant Dis. 70:122125.

14. Hoffmann, J. A. 1982. Bunt of wheat. Plant Dis. 66:979-986.

15. Johnsson, L. 1989. Dwarf bunt (Tilletia contraversa) and bunt (Tilletia caries) in Swedish wheat in 1989. Z. Pflanzenk. Pflanzen. 92:162 167.

16. Johnsson, L. 1992. Dwarf bunt (Tilletia contraversa Kuhn) in winter wheat in Sweden: Relationship to climate (1951-1987) climate, survey results and cultivation (1967-1987). Z. Pflanzenk. Pflanzen. 99:256-265.

17. Jonson, J. O. 1988. Breeding for resistance to bunt in winter wheat. Nord. Jordbrugsforsk. 70:518-519.

18. Keener, T. K., Stougaard, R. N., and Mathre, D. E. 1995. Effect of winter wheat cultivar and difenoconazole seed treatment on dwarf bunt. Plant Dis. 79:601-604.

19. King, A. D., Jr., Ruch, D. L., and Goodman, N. 1991. TCK bunt spores and export wheat. Cereal Foods World 36:509-512.

20. Mather, J. R. 1974. Climatology: Fundamentals and Applications. McGraw-Hill, New York, USA.

21. Mathre, D. E. 1996. Dwarf bunt: Politics, identification, and biology. Annu. Rev. Phytopathol. 34:67-85.

22. Mathre, D. E., and Johnston, R. H. 1976. Presence of dwarf and common smut in Montana wheat. Plant Dis. Rep. 60:580-583.

23. Mathre, D. E., Johnston, R. H., and Grey, W. E. 1990. Effect of seed treatment in preventing transmission of dwarf bunt of winter wheat to new areas. Pestic. Sci. 30:217-222.

24. Mathur, S. B., and Cunfer, B. M., eds. 1993. Seed-borne diseases and seed health testing of wheat. Danish Government Institute of Seed Pathology for Developing Countries, Copenhagen, Denmark.

25. Purdy, L. H., Kendrick, E. L., Hoffmann, J. A., and Holton, C. S. 1963. Dwarf bunt of wheat. Annu. Rev. Microbiol. 17:199-222.

26. Reichert, I. 1958. Fungi and plant diseases in relation to biogeography. Trans. N.Y. Acad. Sci. 20:333-339.

27. Rickman, R. W., Waldman, S. E., and Klepper, B. 1996. MODWht3: A development driven wheat growth simulation. Agron. J. 88:176-186.

28. Ritchie, J. T. 1985. A User-oriented model of the soil water balance in wheat. Pages 293-305 in: Wheat Growth and Modeling. W. Day and R. K. Atkin, eds. Plenum Publishing Corp., New York, USA.

29. Sachs, E. 1954. Zwergsteinbrandbefall in abbangigkeit von verschieddenen Kulturbedingungen. Z. Pflanzenk. Pflanzen. 5:146-151.

30. Sansford, C. E. 2002. Quantitative Versus Qualitative: PRA in the UK and Europe Including the European and Mediterranean Plant Protection Organization System. In: Proc. NAPPO Pest Risk Analysis Sympos., Puerto 


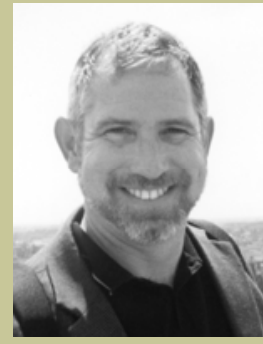

Gary L. Peterson

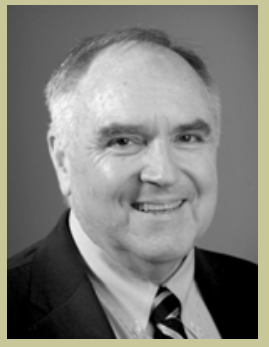

Thomas B. Whitaker

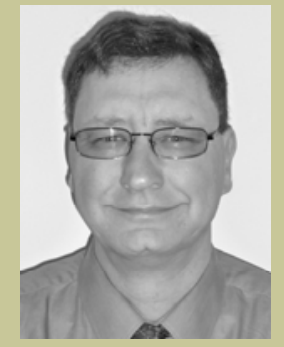

Robert Stefanski

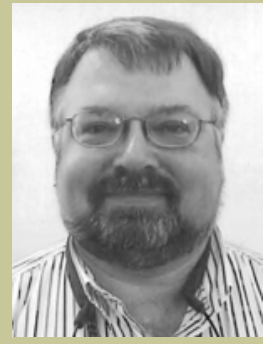

Edward Podleckis

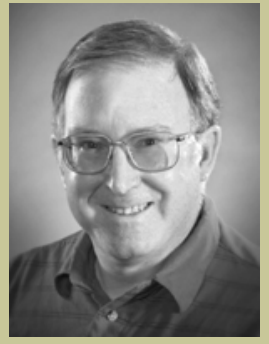

John G. Phillips

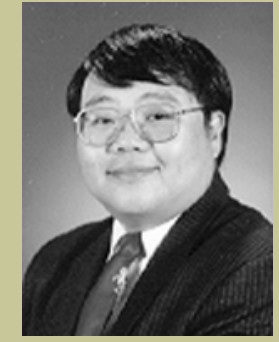

Jeremy S. Wu
Gary Peterson joined USDA's Agricultural Research Service in 1978. He is currently a research biologist at the Foreign Disease-Weed Science Research Unit, Fort Detrick, MD. He received his undergraduate degree in biology from St. Mary's College of Maryland in 1977. His research efforts have focused on new and emerging plant pathogenic fungi as well as fungal plant pathogens that pose trade restrictions on U.S. export markets. A great portion of his career has focused on dwarf bunt and Karnal bunt of wheat. His cooperative research efforts both nationally and abroad have resulted in authorships in more than 50 full-length journal publications. Relative to his work on dwarf bunt trade issues, he has received a USDA Secretary's Award for Superior Service as well a two USDA Secretary's Superior Service Team Awards. His present research focus is the pathotype of Magnaporthe grisea causing wheat blast.

Thomas Whitaker received his B.S. and M.S. in agricultural engineering at North Carolina State University and his Ph.D. from The Ohio State University in 1967. That same year, he joined the USDA-ARS as a research agricultural engineer with the Market Quality and Handling Research Unit in Raleigh, NC. He retired from ARS in February 2009 after 42 years of service with USDA. By characterizing the variability associated with the sampling, sample preparation, and analytical steps used to detect mycotoxins in food and feed, he developed models to evaluate the performance of sampling plans so that effective sampling plans can be designed to accurately detect mycotoxins in the food supply. The evaluation method has been used worldwide by regulatory agencies, food industries, and international organizations such as FAO/WHO to improve export trade and increase consumer protection. Dr. Whitaker is a fellow of the American Society of Agricultural and Biological Engineers and the American Peanut Research and Education Society.

Robert Stefanski is a Scientific Officer in the Agricultural Meteorology Division of the World Meteorological Organization (WMO), a specialized agency of the United Nations based in Geneva, Switzerland. He received his B.S. in agricultural meteorology from Purdue University in 1986 and an M.S. in agricultural climatology from lowa State University in 1988. His work on the TCK paper was done while he was at the World Agricultural Outlook Board of USDA in Washington, D.C. His current work with WMO involves organizing and coordinating international efforts on weather and climate issues related to agriculture such as climate variability/change, drought, and improved communication of weather/climate information to farmers.

Edward Podleckis received his B.S. in plant pathology from Cook College, Rutgers University, his M.S. in plant science from the University of Delaware, and his Ph.D. in plant virology/plant pathology from the University of Maryland. He was a postdoctoral research associate at the Rutgers Blueberry/Cranberry Research Center where his research focused on blueberry scorch virus. He then joined the USDA-ARS as postdoctoral research associate in the Molecular Plant Pathology and National Germplasm
Resources Laboratories where his work centered on the development of detection methods for quarantine pathogens. In 1994, Dr. Podleckis joined the USDA-APHIS Plant Protection and Quarantine staff as a plant pathologist and later as a risk mitigation specialist conducting commodity plant pest risk analyses. Currently, he is a senior analyst with the USDA-APHIS, Policy and Program Development, Risk Analysis Systems staff. He is responsible for analyzing plant pest risks associated with agricultural commodities and the development of risk management strategies to mitigate that risk.

John G. Phillips joined USDA's Agricultural Research Service in 1975 as the consulting statistician for the North Atlantic Area. He received his undergraduate degree in mathematics with distinction from the University of Minnesota in 1969 and his Master of Science and Ph.D. degrees in mathematics from the University of Notre Dame in 1972 and 1974, respectively. He has been involved in research efforts ranging from utilization research such as food safety and microbiology to production research such as plant breeding and pathology. These efforts have resulted in the co-authorship of more than 90 publications. $\mathrm{He}$ was a member of the USDA Superior Service award team for the development of predictive microbial computer models. Dr. Phillips was named a Fellow of AOAC International in 1997.

Jeremy S. Wu is director of the Longitudinal EmployerHousehold Dynamics (LEHD) Program at the U.S. Census Bureau. One of the program products, a web-based online mapping and reporting application, was featured in a 2009 United Nations Statistical Commission seminar as one of the major U.S. statistical innovations. The LEHD Program integrates administrative records with census and survey data to build a time series infrastructure on the characteristics and history of each of the 150 million workers and 190 million jobs in the United States. Dr. Wu received his B.A., M.A., and Ph.D. degrees in mathematical statistics from the George Washington University. Prior to joining the Census Bureau, Dr. Wu served in the U.S. Departments of Agriculture, Energy, and Transportation, most recently as acting chief statistician at the Bureau of Transportation Statistics.

Wilda $\mathrm{H}$. Martinez conceived and led the multiagency, multidisciplinary working group that conducted the supporting research and developed the dwarf bunt risk model presented here. Mrs. Martinez joined the Agricultural Research Service, USDA, in 1954 as a research scientist at the Southern Regional Research Center, New Orleans, LA. In 1975, she moved to the National Program Staff, where she served as Program Leader for Marketing and Processing of Field Crops and later as the Associate Deputy Administrator for Agriproducts and Human Nutrition. From 1997 until her retirement in 2007, she served as the director for the North Atlantic Area. Her vision, scientific expertise, leadership, and dedication have had significant and long-term impact on ARS research programs in crop quality, food safety, nutrition, and development of bioproducts. 
Vallarta, Mexico. Online: http://www.nappo. org/PRA-Symposium/PDF-Final/Sansford.pdf

31. Schonbrunner, J., and Zwatz, B. 1972. Feeding experiments designed to study germination and toxicity of spores of dwarf bunt (Tilletia contraversa Kuhn). Wien-Tierarztl-Monat. 59:361365.

32. Sitton, J. W., Line, R. F., Waldher, J. T., and Goates, B. J. 1993. Difenoconazole seed treatment for control of dwarf bunt of winter wheat. Plant Dis. 77:1148-1151.

33. Sitton, J., Wiese, M., Goates, B. J., Forster, R., Line, R., Mathre, D., Peterson, C., Smiley, R., and Waldher, J. 1994. Dwarf bunt of Winter Wheat in the Northwest. Pacific Northwest Ext. Publ., Pullman, WA, USA.

34. Smilanick, J. L., Dupler, M., Goates, B. J., Hoffmann, J. A., Clark, D., and Dobson, D. 1986. Germination of teliospores of Karnal, dwarf, and common bunt fungi after ingestion by animals. Plant Dis. 70:242-244.

35. Trione, E. J. 1982. Dwarf bunt of wheat and its importance in international wheat trade. Plant Dis. 66:1083-1088.

36. Trione, E. J., and Hall, M. J. 1986. Dwarf bunt of wheat in China: Potential sites from satellite studies. Agron. J. 78:148-150.

37. U.S. Dep. Agric., Federal Gain Inspection Service. 2004. Grain Inspection Handbook, Book II. U.S. Government Printing Office, Washington, DC

38. Vose, D. 2001. Risk Analysis. John Wiley \& Sons, New York, USA.

39. Wei, S., Zhang, Z., and Zheng, Y. 1995. Evaluation on the establishment potential of wheat dwarf bunt with bio-climatic analogical distance model. ACTA Agric. Univ. Pekinesis. 21:1-8.
40. Weltzien, H. C. 1967. Geopathologie der pflanzenschitz. Z. Pflanzenk. Pflanzen. 74:176189.

41. Weltzien, H. C. 1972. Geophytopathology. Annu. Rev. Phytopathol. 10:277-298.

42. Whitaker, T. B., Wu, J. S., Peterson, G. L. Giesbrecht, F. G., and Johansson, A. S. 2001. Variability associated with the official USDA sampling plan used to inspect export whea shipments for Tilletia controversa spores. Plant Pathol. 50:755-760.

43. Zadoks, J. C. 1991. Coping with Climatic Variation in Plant Disease Control. Pages 269 276 in: Climate and Food Security. International Rice Research Institute, Manila, Philippines.

44. Zhang, Z., Zhang, C. R., and Wang, Z. Z 1995. Plant quarantine significance of dwarf bunt of wheat in China. EPPO Bull. 25:665-671. 